\title{
KİSRÂ SARAYINDAN KERBELÂ SAHRASINA: MİLLÎ-DİNÎ KİMLİK UNSURU VE TARİHÎ- MENKİBEVÎ FİGÜR ARASINDA MAKTELLERDE ŞEHRBÂNÛ
}

\author{
Elnura AZIZOVAa
}

$\ddot{0} \mathbf{z}$

61/680 yılında vukû bulmuş Kerbelâ Olayı'nı tarihî bir vaka olarak ele alan Maktelü'l-Hüseyn'ler, zamanla özel bazı siyasî-dinî sebeplerin yanında genel olarak Müslüman halkların Resûlullâh'a ve onun Ehl-i Beyt'ine olan sevgisiyle, torununun az sayıda taraftarıyla birlikte acımasızca katledilmesinden duydukları acıyı birleștirdikleri duygu yüklü tarihî-edebî eserlere dönüştürülmüşler. Tarihî eserden tarihî-edebî esere geçiş sürecinde maktellere müellifinin görüşlerine paralel olarak, okuyan veya dinleyen kitlenin dinî, siyasî, millî ve kültürel beklentilerine uygun bazı unsurlar da eklenmiştir. İlk örnekleri Arapça yazılan Maktelü'l-Hüseyn'lere okuyucu ve dinleyici kitlenin zevkine uygun olarak eklenen en önemli gayr-i Arap kültür öğesi, Hz. Hüseyin'in eşi, Ali b. Hüseyin Zeynelâbidîn'in annesi olduğu ileri sürülen tarihî-menkibevî figürdür. Diğer isimlerinin yanında özellikle Farsça ve Türkçe maktellerde Şehrbânû olarak geçen bu şahsın Hz. Hüseyin'le evliliğinden vefatına kadarki olaylarla ilgili tarih kaynaklarında çelişkili bilgiler bulunmaktadır. Kaynaklardaki bu çelişkili bilgiler, Şehrbânû imajının ortaya konduğu en önemli tarihî-edebî tür olarak maktellerde de görülmektedir. Bu makalede döküman incelemesi yöntemi kullanılarak Ali b. Hüseyin'in annesiyle ilgili ilk dönem kaynaklarındaki tarihî bilgiler değerlendirilecektir. Ardından içerik analizi tekniğiyle Arapça, Farsça ve Türkçe belli başlı Maktelü'l-Hüseyn'lerdeki Şehrbânû imajı araștırılacaktır. Son olarak makalede karşılaştırmalı analiz yöntemi uygulanarak Şehrbânû örneğinden hareketle müslüman halkların müșterek tarihî-edebî türü olan maktel yazımına millî, dinî, siyasî ve kültürel unsurların etkisi araştırılacaktır.

Anahtar kelimeler: İslam Tarihi, Kerbelâ, Hz. Hüseyin, Maktel, Şehrbânû.

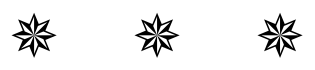

\footnotetext{
a Doç. Dr., Azerbaycan İlahiyat Enstitü, elnuraazizova@ait.edu.az
} 


\section{FROM THE PALACE OF KISRĀ TO THE DESERT OF KARBALĀ: SHAHRBĀNŪ IN MAQTALS BETWEEN A NATIONAL-RELIGIOUS IDENTITY ELEMENT AND A HISTORICAL-LEGENDARY FIGURE}

The Maqtal al-Husayns, first written on the Karbalā Event (61/680) as a historical case, have been gradually transformed into emotional historical-literary works where along with some certain political-religious reasons, Muslims combined their love towards the Prophet Muhammad and his family, as well as the pain they felt from the brutal murder of his grandson with a small number of his followers. During the process of transition from historical works to historicalliterary ones, some elements in line with the religious, political, national and cultural expectations of the readers or listening audience were added to the maqtals, in parallel with the views of the author. The most important non-Arab cultural element according to the taste of the readers and listeners added to the Maqtal al-Husayns, first examples were written in Arabic, is the historicallegendary figure claimed to be Ḥusayn ibn 'Alī's wife and 'Alī ibn Husayn Zaynalābidīn's mother, among other names who is called Shahrbānū in Persian and Turkish maqtals. The information in the historical sources about the events related to her marriage to Husayn ibn 'Alī until her death is contradictory. This conflicting information from sources was also reflected in the maqtals, as the most important historical-literary genre in which the image of Shahrbānū was revealed. Using document analysis method this article will evaluate the historical information from the sources about 'Ali ibn Husayn's mother. Then, with the content analysis technique, the image of Shahrbānū will be investigated within the contexts of major examples of Arabic, Persian and Turkish maqtals. Finally, applying the comparative analysis method and based on the example of the image of Shahrbānū, the article will investigate the effects of national, religious, political and cultural factors on the process of transformation of the maqtals as the common historical-literary form of the Muslim peoples.

[The Extended Abstract is at the end of the article.]

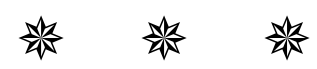

\section{Giriş}

Hz. Peygamber'in Kerbelâ'da şehîd olmuş torunu Hz. Hüseyin'in soyunu devam ettiren tek evlâdı olarak Ali b. Hüseyin Zeynelâbidîn'in annesinin kimliğiyle ilgili İslam literatüründeki veriler onun ismi, memleketi, hür veya köle olması gibi genel karakterli bilgilerin yanında, hangi halifenin döneminde ve hangi şartlarda esir alındığı, esirlik sürecinde nasıl muamele gördügü̈, hangi şartlarda Hz. Hüseyin'le evlendiği, kendisiyle birlikte esir alınan kızkardeș(ler)inin kim(ler)le evlendirildiği ve bu evlilik(ler) yoluyla sahabî çocukları arasında kurulan akrabalık(lar), Hz. Hüseyin'in 
şehadetinden sonra evlenip evlenmediği ve ne zaman vefat ettiği gibi, aynı zamanda kaynağın yazıldığı dönemin dinî-siyasî içerikli bazı polemiklerini yansıtması açısından da önem arzeden farklı detaylara sahiptir. " "Gazâle", "Sülâfe", "Harâre", "Cûde", "Helvâ", "Selâme", "Şâhâferîd", "Seyyidetü'l-beled", "Keyhâh Bânuye", "Şâhzenân" vs. gibi isimlerinin yanında kaynaklarda "Şehrbânû" isimli Sâsâni prensesi olarak da geçen bu şahısla ilgili bilgiler sadece Ali b. Hüseyin'in annesi olmasıyla sınırlı kalmamış, Hz. Ali'nin Farsça konuşabildiği ${ }^{2}$, Ali b. Hüseyin'in Fars kraliyet ailesi sebebiyle Farsların akrabası olması ve Farsların Araplarla birlikte seçilmiş iki halk olduğ ${ }^{3}$ şeklinde millî kimlik bağlamında önem arzeden konular çerçevesinde de kaynaklara geçmiştir. ${ }^{4}$

Şehribânû'yla ilgili araştırmasında Amir-Moezzi onun Ali b. Hüseyin'in annesi olduğuna dair İslâm literatüründeki rivayetlerin, kendisi de Fars anneden doğan Abbâsî halifesi Me'mûn'un (813-833) Abbâsiler, Ali evladı ve Farslar arasında ittifak kurma politikası yürüttüğü ve 8. imâm Ali er-Rızâ'yı

1 İbn Sa'd, Gazâle isimli ümmüveled olduğunu aktarmakta (Ebû Abdullah Muhammed b. Sa'd, Kitâbü't-Tabakâti'l-Kebîr, thk. Ali Muhammed Ömer (Kâhire: Mektebetü'l-Hancî, 1421/2001), 7:209); İbn Kuteybe’ye göre Sülâfe veya Gazâle olarak adlandırılmıș, Hz. Hüseyin'in vefatından sonra Zübeyid'le evlenerek Abdullah b. Zübeyid'i doğurmuş (Ebû Muhammed İbn Kuteybe, el-Ma'ârif, thk. Servet 'Ukkâşe (Kahire: Dârü'l-Ma'ârif, 1981), 214-215); Ya'kubî’ye göre Harâre bint Yezdicerd, Hz. Hüseyin tarafından Gazâle olarak isimlendirilmiștir (Ahmed b. İshâk b. Cafer el-Ya'kubî, Târîhu'lYa'kubî (Necef: Mektebetü'l-Haydariyye, 1384/1964), 2:233). Şehrbânû ve kızkardeşleri sebebiyle sahabî çocukları arasında kurulan akrabalıklar için bkz. Ebû Muhammed İbn Kuteybe, Fazlu'l-'Arab ve't-tenbîh 'alâ 'ulûmihâ, thk. Velîd Mahmûd Hâlis (Ebûzabî: el-Mecmaü's-Sekâfî, 1998), 48; Ali b. Hüseyin'in annesiyle ilgili 8. imâm Rıza'ya nisbet edilen rivayete göre, Hz. Osman döneminde esir alınan Yezdicerd'in kızları Hz. Hüseyin ve Hz. Hasan'la evlendirilmiş, kızlar doğum yaptıklarında vefat etmiş, Zeynelâbidîn kendisini büyüten babasının ümmüveledlerinden birini annesi bilmiş, daha sonra onu evlendirmiştir (Bkz. Muhammed b. Ali Şeyh Sadûk, 'Uyûnü ahbâri'r-Rızâ (yy.ty.), 2:135136). Hz. Ali döneminde Yezdicerd'in müslümanlarca ele geçirilen iki kızından biri olan Şehrbânû/Şah-zenân'ın Hz. Hüseyin'le evlenip Ali b. Hüseyin'i doğurduğuna, Muhammed b. Ebû Bekir'le evlendirilen diğer kızın Kâsım'ı doğurduğuna dair Bkz. Şeyh Müfîd, el-İrşâd fí ma'rifeti hücecillâhi 'ale'l-ibad (Beyrut: Müessese Âli Beyt ve ihyâu't-turâs, 1429/2008), 2:137. Dîneverî'nin rivayetine göre, Hz. Ali döneminde Nîsabûr'da isyan eden halk Kâbil'den gelen Kisrâ kızını kendilerine lider yapmış, isyan bastırıldıktan sonra Hz. Ali kendisine gönderilen Kisrâ'nın kızına Hz. Hasan'la evlenmeyi önermişse de, kız "Kendisi yönetilen birisiyle evlenmem, istersen seninle evlenirim" cevabını vermiştir. Hz. Ali'nin yaşlı olması sebebiyle kabul etmediği bu öneri sonucunda Yezdicerd'in kızının son kararıyla ilgili bilgi verilmemektedir (Ebû Hanîfe ed-Dîneverî, Ahbâru't-tıvâl, thk. 'Abdülmünîm Âmir (yy. ty), 153-154).

'Ebû Ca'fer Muhammed b. Hasan Saffâr Kummî, Besâirü'd-derecât fî fazâili Âl-i Muhammed, thk. Müessesetü'l-İmâmi'l-Mehdî (Kum: İ'timâd, t.y.), 1:593-594.

${ }^{3}$ Hz. Peygamber'e nisbet edilen "Allah'ın mahlukatı arasında iki hayırlıdan biri Araplardan Kureyș, diğeri Acemlerden Farslardır" sözlerine dayanarak Ali b. Hüseyin'in “iki hayırlının oğlu” (zü’lhiyarateyn) adlandırıldığına, Hz. Ali döneminde Yezdicerd'in kızının yüz esir kızla birlikte Hz. Ali'nin huzuruna getirildiğine, Hz. Hüseyin'le evlenmesi önerilen prensesin "efendisi olan birisi benim gibisine efendilik edemez" cevabı vererek Hz. Ali'nin kendisiyle evlenmek istediğine dair rivayet için Bkz. Müberred, Kitâbü'l-Fâzıl ve'l-mefzûl, thk. Abdülazîz el-Meymenî (Kâhire: Dârü'l-kütübi'lMısriyye, 1995), 106; Benzer konudaki rivayet için bkz- Ebû Câfer el-Küleynî, el-Usûl mine'l-Kâfî, thk. Ali Ekber el-Gaffârî (Tahran: Dârü'l-Kütübi'l-İslâmiyye, 1363hş), 1: 466-467.

${ }^{4}$ Rivayetler için bkz. Ebü'l-Hasan Ali b. Zeyd Beyhakî, Lübâbü'l-ensâb ve'l-elkấb ve'l-a'kâb, thk. Seyyid Mehdi Recâî (Kum: Âyetullâhi'l-'Uzmâ el-Mar'aşî, 1990), 1: 346-352. 
veliaht olarak atadığı kısa sürelik dönemde (200-203/815-818 yılları) ortaya çıktığını ileri sürmektedir. Amer-Moezzi'ye göre, baba tarafından Benî Hâşîm'in devamcısı olan Ali er-Rızâ böylece, Fars kraliyet ailesine mensup büyükanneyle de onurlandırılmıştır. ${ }^{5}$ Fetihlerin ardından Farsların müslümanlaşma sürecini araştıran eserinde Sarah Bowen Savant da AmirMoezzi'nin argümanına ek olarak Yezdicerd'in kızı Şehribânû'nun Ali b. Hüseyin'in annesi olmasıyla ilgili rivayetlerin daha sonraki dönemlerde siyasî, dinî ve millî açıdan anlamlı detaylar eklenerek geliştirildiğini ileri sürmektedir. ${ }^{6}$

Diğer taraftan sonuncu Sâsânî prensesi imajı örneğindeZerdüştî ve Müslüman Farslar arasındaki ortak külte dikkat çeken Mary Boyce, İran'ın Yezd bölgesindeki ünlü Zerdüştî ziyaretgâhı Bânû-Pârs ile Müslümanların Rey yakınındaki Bîbî Şehribânû ziyâretgâhının temelini oluşturan menkıbeler arasındaki paralelliği vurgulamaktadır. Bu menkıbelerin en önemli ortak yönü, her ikisinin de son Sâsânî prensesinin düşman takibinden kaçarken mucizevî şekilde sığındığına inanılan dağın kutsal sayılmasıdır. Menkıbeleri ayıran özellik ise, hükümdar kızı Bânû-Pars'ın Sâsânîler'in hâkimiyetine son veren Müslüman Araplar; Bîbî Şehribânû'nun ise Kerbelâ olayının ardından Emevî ordusu tarafından takip edilmesidir. ${ }^{7}$ Kerbelâ olayının klasik kaynaklardaki kısa ve tafsilatlı anlatımını karşılaştırdığı makalesinde Antoine Borrut, kesin sınırları belli olan erken dönem Arapça maktel türünden başka, özellikle Şîi edebiyatta Kerbelâ'nın hafızalarda tutulmasının alternatif yollarının da düşünüldüğünü, bu anlamda olaya bazı edebî ve efsânevî ayrıntıların eklendiğini ve Sâsânî prensesi Şehrbânû imajının bu konuya en iyi örnek oluşturduğunu kaydetmektedir. ${ }^{8}$

Müslümanların kültürel hâfızasının oluşumunda önemli rol oynamış tarihî-edebî eserlerden olan maktellerle ilgili çok sayıda çalışma yapılmakla birlikte9 Arapça, Farsça ve Türkçe makteller arasında mukâyeseli araştırmalar yok denecek kadar azdır. Bu çalışmada Ali b. Hüseyin

${ }^{5}$ Mohammad Ali Amir-Moezzi, “Shahrbānū, Dame du Pays D’Iran et Mère Des Imams: Entre L’Iran Préislamique Et Le Shiisme Imamite", Jerusalem Studies in Arabic and Islam 27 (2002): 523-524.

${ }^{6}$ Sarah Bowen Savant, The New Muslims of Post-Conquest Iran: Tradition, Memory, and Conversion (New York: Cambridge University Press, 2013), 102-108.

${ }^{7}$ Mary Boyce, Bîbî Șehribânû'yu Zerdüștîlerin Bânû-Pars kültü ile, onu ise bereket ve doğum tanrıçası Anahit inancı ile iliş̧kilendirmektedir. Mary Boyce, "Bībī Shahrbānū and the Lady of Pārs", Bulletin of the School of Oriental and African Studies, 30/1 (1967): 30-44. Amer-Moezzi de İslam öncesi İran hatunu ile Şiî-Farslar tarafından İmamların anası olarak kabul edilen Şehribânû arasındaki ilişkiye dikkat çekmektedir. Bkz. Amir-Moezzi, "Shahrbânû", 525-532.

${ }^{8}$ Antoine Borrut, "Remembering Karbalā: the construction of an early Islamic site of memory", Jerusalem Studies in Arabic and Islam, 42 (2015): 253.

${ }_{9}^{9}$ Liste için bkz. Sibel Özil, "Maktel-i Hüseyinler Hakkında Bir Bibliyografya Denemesi”, Türk Kültürü ve Hacı Bektaş Veli Araştırma Dergisi 83 (2017): 31-48. 
Zeynelâbidîn'in annesi olduğu ileri sürülen Şehrbânû karakteri özelinde Arapça, Farsça ve Türkçe makteller arasındaki ilişki ve etkileşim değerlendirilecek, millî, dinî ve menkibevî unsurlar açısından Sâsânî prensesinin maktellerdeki yeri analiz edilecektir.

\section{A. Arapça Maktellerde Șehrbânû: Önem Arz Etmeyen Gayr-i Arap Unsur}

İlk örnekleri tarihî eser olarak yazılmakla birlikte zamanla tarihî-edebî türe dönüşen Arapça maktellerin ${ }^{10}$ günümüze ulaşanları içerik açısından incelendiğinde Kerbelâ olayı sırasında kendilerinden bahsedilen Ehl-i Beyt kadınlarının genellikle Ali-Fâtıma evladına mensup oldukları görülmektedir. Kerbelâ olayı sırasında, Hz. Hüseyin'in şehid edilmesinin ardından çadırların yağmalanması sırasında, Kûfe'de Ubeydullah b. Ziyâd'ın huzurunda, Dımaşk yolculuğunda ve Yezîd'in sarayında, Medîne'ye dönüşte kendilerinden bahsedilen kadınlar arasında Hz. Hüseyin'in eși veya Ali b. Hüseyin Zeynelâbidîn'in annesi olması bağlamında Şehrbânû'dan sözedilmemektedir. Erken dönem maktel yazarlarından Ebû Mihnef'e (ö. 157/773-774) nisbet edilen Maktelü'l-Hüseyn'de olduğu gibi, Taberî'nin Ebû Mihnef'ten aktardığı Maktelül-Hüseyn'de Kerbelâ olayı ve sonrasında Zeyneb, Rukiyye, Ümmü-külsûm ile Sükeyne'den bahsedilirken ${ }^{11}$ Şehrbânû'dan sözedilmemektedir. Bir diğer ünlü Arapça maktel olan Ebü'lFerec el-İsfahânînnin(ö. 356/967) Mekâtilü't-Tâlibiyyîn adlı eserinin Kerbelâ'yla ilgili kısmında da aynı durum söz konusu olup Zeyneb bt. Ali gerek Kerbelâ'da, gerekse olayın ardından Kûfe'ye ve Dımaşk'a götürülürken Ehl-i Beyt'i koruyup kollayan kadın olarak gösterilmektedir. ${ }^{12}$ Zeynelâbidîn'in annesinin ümmüveled olduğunu kaydetmekle yetinen ${ }^{13}$ İsfahânî'nin, muhtemelen kendisinin de mensûb olduğu Ümeyyeoğulları'nı övme amacıyla Hz. Hüseyin'in Kerbelâ'da şehid edilmiş bir diğer oğlu Ali b. Hüseyin'in annesi Leylâ bt. Ebû Mürre'yle ilgili Muâviye b. Ebû Süfyân'dan aktardığı detay dikkat çekmektedir. ${ }^{14}$ İsfahânî̀nin çağdaşı olan hadis alimi

\footnotetext{
10 Bkz. Sebastian Günther, "Maqatil Literature in Medieval Islam”, Journal of Arabic Literature 25 (1994): 192-212; Khalid Sindawi, “The Image of Ḥusayn Ibn 'Alī in "Maqātil Literature", Quaderni di Studi Arabi 20-21 (2002-2003): 79-104.

11 Ebû Mihnef Lût b. Yahyâ, Maktelü'l-Hüseyn ve masra'u ehli beytihi ve ashâbihi fî Kerbelâ (Kum: Menșûrât-i Rizâ, 1391), 129-133, 154-155. Krş. Muhammed b. Cerîr et-Taberî, Târîhü't-Taberî: Târîhu'l-ümem ve'l-mülûk, thk. Muhammed Ebü'l-Fadl İbrâhîm (Beyrut: Dârü Süveydân, 1967), 5:446-447, 452, 456-457.

12 Ebü'l-Ferec el-İsfahânî, Mekâtilü't-Tâlibiyyîn, thk. es-Seyyid Abbas Ahmed Sakr (Beyrut: Dârü'lMa'rife, 1946), 115-116.

13 el-İsfahânî, Mekâtilü't-Tâlibiyyîn, 119.

${ }^{14}$ Ali b. Hüseyin'in annesinin Leylâ bint Ebû Mürre es-Sakafî, Leylâ'nın annesinin ise Meymûne bint Ebû Süfyân b. Harb olduğu için, Ali b. Hüseyin'in Benî Hâşim'in şecâati, Benî Ümeyye'nin cömertliği
} 
Süleyman b. Ahmed et-Taberânî̀ye (ö. 360/971) atfedilen Maktelü'lHüseyn'de Hz. Hüseyin'in Kerbelâ'da katledilen çocuklarının annelerinin isimlerini ihtivâ eden listede ${ }^{15}$ veya herhangi bir bağlamda Ali b. Hüseyin'in annesi olarak Şehrbânû'dan bahsedilmemektedir.

Daha geç dönem Arapça maktellerden, VII./XIII. yüzyılın ünlü İsnâaşeriyye alimi İbn Tâvûs'un (664/1266) Hz. Hüseyin'in meşhedini ziyaret edenlerin kendileriyle birlikte getirmesi amaciyla yazdığ ${ }_{1}^{16}$ el-Lühûf fi qatle't-tüfûf unda da Kerbelâ kadınları arasında Zeyneb, Ümmü-külsûm, Rukıyye, Fâtıma, Rebâb, Sükeyne'den bahsedilirken, ${ }^{17}$ Şehrbânû'dan söz edilmemektedir. Yaklaşık aynı döneme ait İmâmiyye alimlerinden İbn Nemâ el-Hillî'nin (ö. 645/1247-48) Musîru'l-ehzân isimli Arapça maktelinde de Şehrbânû'dan bahsedilmezken, Zeyneb Kerbelâ kadınları arasında en etkin figür olarak gözükmektedir. ${ }^{18}$

İranlı İmâmiyye alimi İbn Şehrâşûb’un (ö. 588/1192) Ali evladına dair kaleme aldığı, önemli bir faslını Hz. Hüseyin'e ve Kerbelâ olayına tahsîs ettiği Menâkibü âli Ebî Tâlib isimli eserinde aktardığı bilgilerin, Kerbelâ olayı bağlamında Şehrbânû'yla ilgili veriler açısından bir istisnâ oluşturduğu söylenebilir. İbn Şehrâşûb Hz. Ömer döneminde Medine'ye getirilen Fars esirler arasında bulunan Yezdicerd'in iki kızının Hz. Ali tarafından özgür bırakıldığını, birisinin Hz. Hüseyin, diğerinin Muhammed b. Ebû Bekir'le evlendirildiğini kaydetmektedir. ${ }^{19}$ Yezdicerd'in kızı için diğer isimlere göre Şehrbânû ismini doğru bulan İbn Şehrâşûb ${ }^{20}$, onun Kerbelâ sonrasında Kûfe'ye götürülen diğer Ehl-i Beyt üyeleri arasında bulunmadığını, nitekim Hz. Hüseyin'in şehadetinin ardından kendisini Fırat'a atarak öldürdüğünü nakletmektedir. ${ }^{21}$

Erken dönem Arapça örneklerden farklı olarak, Türk-Fars kültür çevrelerinde yetişmiş gayri-Arap müelliflere ait geç dönem Arapça maktellerde Şehrbânû'dan bahsedilmektedir. Fâzıl Derbendî olarak bilinen Kaçarlar (1796-1925) dönemi din alimi Ağa b. Âbid'in (ö. 1285/1870)

ve Benî Sakîfin büyüklüğü gibi meziyetleri kendisinde birleştirdiğine dair Muâviye b. Ebû Süfyân'ın rivayeti için bkz. İsfahânî, Mekâtilü't-Tâlibiyyîn, 80.

${ }^{15}$ Süleyman b. Muhammed et-Taberânî, Maktelü'l-Hüseyn, thk. Muhammed Şecâ Dayfullâh (Küveyt: Dârü'l-evrâdi, 1412/1992), 38.

16 Ali b. Mûsâ İbn Tâvûs, el-Lühûf fí katle't-tüfûf (Beyrut: Müessesetü'l-'ilmiyyi li'l-matbû'ât, 1414/1993), 87.

17 İbn Tâvûs, el-Lühûf, 140-141, 147, 151, 167-169, 181, 220.

18 Örneğin bkz. İbn Nemâ el-Hillî, Müsîrü'l-ehzân va münîrü sübüli'l-eşcân (Kum: Matba'atü'l-Emîr, 1406), 49, $69 \mathrm{vd}$.

${ }^{19}$ Reșîuüddin Muhammed İbn Şehrâş̧ûb, Menâkıbu âli Ebî Talib, thk. Yûsuf el-Bekâ'î (Beyrut: Dârü'l-

${ }^{21}$ İbn Şehrâşûb, Menâkib, 4:121. 
İksîrü'l-'ibâdât isimli Arapça maktelinde, Hz. Hüseyin'in şehadetinden sonra Şehrbânû'nun kendisini Fırat'a attığına dair İbn Şehrâşûb'dan gelen bilgilerin doğru olmadığı, bahsedilen kadının Ali b. Hüseyin'in annesi ve Yezdicerd'in kızı Şâhzenân olamayacağı; zîrâ Şâhzenân'ın Zeynelâbidîn'i doğururken vefat ettiğini bildirir. ${ }^{22}$ Müellif Hz. Hüseyin'in eşi olarak Sâsânî prensesiyle ilgili kendi döneminde İran kültür çevresinde bilinen menkıbevî bir rivayeti aktarmaktadır: "Mûteber tarih kitaplarında" geçen bu rivayete göre Kerbelâ'ya katılan Şehrbânû Ali b. Hüseyin'in değil, Kâsım'ın eşi Fâtıma'nın annesidir. Hz. Hüseyin'in şehâdetinin ardından vasiyeti üzerine onun atıyla Rey'e giden Şehrbânû, kendisiyle birlikte götürdüğü kızı Fâtımâ'yı "dayıları kefil olur" umuduyla Rey yakınında bir yerde bırakmış, kendisi ise o civardaki bir dağda kaybolmuştur. Fâzıl Derbendî Rey yakınlığındaki bu dağın tepesinde Şehrbânû'nun elbisesinin bir kısmının hâlâ gözüktüğüne, bu dağa "erkek bebek bekleyen hâmile kadınların" yaklaşamadığına dair halk inancını da eklemektedir. ${ }^{23}$ Derbendî'nin aktardığı bu menkıbevî rivayet en geç XV. yüzyılda İran'da var olduğu anlaşılan "Bîbî Şehrbânû" kültünün XIX. yüzyılda da devam ettiğini göstermektedir.

Fars kültür çevresinde yetişmiş son dönem İmâmiyye alimlerinden Abbas Kummî'nin (ö. 1294-1359/1875-1941) Nefesü'l-mehmûn isimli Arapça maktelinde de Yezdicerd'in kızı Şahzenân'la ilgili Şeyh Müfîd'den aktarılan rivayete yer verilmektedir. ${ }^{24}$ Ali b. Zeynelâbidîn'in annesinin kimliği konusunda farklı rivayetlere yer veren müellif, asıl isminin "Sülâfe", lâkabının "Şâhzenân" olduğuna, Hz. Ali tarafından "Şehrbânû" ismi verildiğine dair rivayetleri tercih etmektedir. ${ }^{25}$ Doğduğunda annesini kaybeden Ali b. Hüseyin'in babasının ümmüveledlerinden birisi tarafından büyütüldüğünü aktaran Kummî, böylece onun daha sonra evlendirdiği bu kadının kendi annesi olduğuna dair iddiaları da tekzîb etmektedir. ${ }^{26}$ Kummî, Kerbelâ esirlerinin Kûfe'den Dımaşk'a yolculukları sırasında Halep yakınlarında bir yerde Hz. Hüseyin'in ismi zikredilmeyen eşinin erken doğum yaptığından ve Muhassin ismi verilen bu çocuğun vefat ederek doğduğu yerde defnolunduğundan, bahsi geçen yerde Hemdâni emiri Seyfüddevle (ö. 356/967) tarafından "Meşhedü's-sakt" isimli bir meşhed

${ }^{22}$ Ağa ibn Âbid Fâzll Derbendî, İksîru'l-'ibâdât fî esrâri'ș-șehâde, thk. Șeyh Muhammed Cumabâdî (Manama: Şirketü'l-Mustafâ li'l-hademâti's-sakâfiyye, 1994), 3:133.

23Fâzıl Derbendî, Íksîru'l-'ibâdât, 3:137-138.

24 Abbas ibn Muhammed Riza el-Kummî, Nefesü'l-mehmûn fî musîbeti Seyyidine'l-Hüseyni'l-

Mazlûm(Beyrut: Dârü'l-Mehecceti'l-beydâ, 1992), 476.

${ }^{25}$ Abbas Kummî, Nefesü'l-mehmûn, 478-479.

${ }^{26}$ Abbas Kummî, Nefesü'l-mehmûn, 479. 
yaptırıldığından bahsetmektedir. ${ }^{27}$ İleride üzerinde durulacağı üzere, olay kurgusu birbirinden tamamıla farklı olmakla birlikte Farsça ve Türkçe maktellerde Halep şehrinin Şehrbânû'yla ilgili rivayetler bağlamında özel bir konumu bulunmaktadır.

\section{B. Farsça Maktellerde Şehrbânû: Makteli Farslaştırma Unsuru}

Erken dönem Arapça örnekleriyle kıyaslandığında Farsça maktellerde ${ }^{28}$ Kerbelâ kadınları arasında Şehrbânû'yla ilgili bilgiler önemli miktarda ve kesinlik arz eden yapıda olup, ayrıca detaylarında millî-dinî açıdan anlamlı mesajlar da içermektedir. Hüseyin Vâiz-i Kâşifínnin (ö. 910/1504-1505) geniş bir coğrafyaya yayılması nedeniyle "ravzahân" diye adlandırılan özel okuyucu kesimin ortaya çıkmasına sebep olacak kadar ünlü Ravzatü'ş-şühedâ'sı Şehrbânû'yla ilgili bu tespiti doğrulayan önemli bir Farsça maktel örneğidir. Kerbelâ'ya katılan Ehl-i Beyt kadınları arasında AliFâtıma evladını ön plana çıkaran Arapça maktellerden farklı olarak Kâşifî’nin Ravzatü'ş-şühedâ'sında Şehrbânû özel bir konuma yerleştirilmektedir. Kerbelâ'da konakladıklarında başlarına gelecek musîbetin ardından feryâd u figân ederek ağlamaması için Hz. Hüseyin'in Şehrbânû'yu özellikle uyarmasi; ${ }^{29} 9$ Muharrem gecesi ev halkına genel anlamda vasiyette bulunduğu halde, kendisinden sonra Şehrbânû'ya babasız kalacak çocuklarının acılarına nasıl tahammül edeceğini sorması; ${ }^{30}$ Ali $b$. Hüseyin'in(Aliyy-i Ekber) Kerbelâda şehid olmasl ${ }^{31}$ ve Hz. Hüseyin'in bebeğinin boğazından okla vurulması sahnesinde ${ }^{32}$ Şehrbânû'nun ağıt yakması; soyunu devam ettirecek oğlu Ali'ye vasiyetinin ardından savaş meydanına giden Hz. Hüseyin'e silahlarını vererek kendisini en son yolcu eden aile üyesi olarak Şehrbânû'nun gösterilmesi ${ }^{33}$ gibi örneklerle Şehrbânû Hz. Hüseyin'in defalarca özel hitap ettiği ve kendisinden sonra çocuklarının sorumluluğunu üstlenmesini istediği eşi olarak takdim edilir.

Kâşifînnin Şehrbânû'yla ilgili üzerinde durduğu bir diğer husus, Hz. Hüseyin'in şehadetinin ardından kendisine dokunulmayacağına dair güvencedir. Hz. Hüseyin'in șehid edileceğini anlayan Şehrbânû kendisinin

${ }^{27}$ Abbas Kummî, Nefesü'l-mehmûn, 611-613.

${ }^{28}$ Farsça maktellerle ilgili bkz. Charles Ambrose Storey, Persian Literature: a bio-bibliographical survey, (London: The Royal Asiatic Society 1970-72), 1/1: 212-235; Ertekin, "Arapça, Farsça ve Türkçe Maktel-i Hüseyinler”, Âşinâ Dergisi 7/23-24 (2006): 84-86; Elnure Azizova, Kerbelâ Vak'ası (İstanbul: Marmara Üniversitesi, SBE, Yüksek Lisans Tezi, 2001), 102-110.

${ }^{29}$ Mevlânâ Kemâlüddîn Hüseyin b. Alî-i Beyhakî el-Kâşifî, Ravzatü'ş-şühedâ, Thk. Hasan Zülfikârî - Ali

Tasnimi (Tahran: Mu'în, 1390), 491-492.

${ }^{30}$ Kâşifî, Ravzatü'ş-șühedâ, 510-511.

${ }^{31}$ Kâşifî, Ravzatü'ş-şühedâ, 609-610.

${ }^{32}$ Kâşifî, Ravzatü'ş-șühedâ, 613-614.

33 Kâşifî, Ravzatü'ş-şühedâ, 616. 
garip olduğunu, Hz. Peygamber sebebiyle diğer Ehl-i Beyt kadınları saygı görecekken düşmanların kendisine eziyet edeceğinden duyduğu endişeyi iletince Hz. Hüseyin, kimseden zarar görmeyeceğini ve ebedî olarak kendisine saygı duyulacağını vadetmiştir. ${ }^{34} \mathrm{~Hz}$. Hüseyin'in şehid edilmesinin ardından atının Şehrbânû'ya geleceğini ve onu Allah'ın takdîr ettiği yere götüreceğini vasiyet ettiğine dair bir diğer rivayetten de bahseden Kâşifi bu rivayetin doğru olmadığını, Şehrbânû'nun Dımaşk yolculuğu sırasında da Hz. Hüseyin'in yakınları arasında bulunduğunu kaydetmektedir. ${ }^{35}$ Kâşifî'nin doğru bulmadığı yukarıdaki rivayet XV. yüzyılın sonu, XVI. yüzyılın başlarında Fars kültür çevresinde Şehrbânû kültünün gelişim sürecinden de haber vermektedir.

Konuyla ilgili Kâşifi'nin maktelindeki en önemli husus Kisrâ Yezdicerd'in Şehrbânû/Şâhzenân olarak isimlendirilen kızının Hz. Hüseyin'le evlenmesi sayesinde Zeynelâbidîn'in "peygamberlikle melikliği birleştirdiği”nin vurgulanmasıdır ${ }^{36}$. Kâş̧ifî, sadece Zeynelâbidîn'in değil, anne ve baba bir kızkardeşi Fâtıma sebebiyle Hz. Hasan'ın soyunun da peygamberlikle melikliği birleştirmiş olduğunu ileri sürmektedir. ${ }^{37}$ Böylece, klasik Arapça maktellerde Hz. Hüseyin'in eşi ve soyunu devam ettiren çocuğunun annesi olarak kendisinden bahsedilmeyen Şehrbânû, Kâş̧ifínin maktelinde sadece Kerbelâ kadınları arasında özel bir konuma getirilmemekte, aynı zamanda peygamberlikle melikliğin birleșmesine hizmet eden bir Sâsânî prensesi olarak sunulmaktadır.

Ününü müellifinin dinî otoritesine borçlu olan bir diğer Farsça maktel Safevî döneminin meşhûr İmâmiyye alimi ve şeyhülislamı Muhammed Bâkır el-Meclisînnin (ö. 1110/1698-99 [?]) Cilâ'ü'l-'uyûn adlı eserinde Şehrbânû'nun hayatıyla ilgili anlatılanlar yaklaşık üç asır önce yazılmış Ravzatü'ş-şühedâ'dan büyük ölçüde farklıdır. Meclisî Hz. Hüseyin'in çocukları ve hanımları hakkında bilgi verirken Ali b. Hüseyin Zeynelâbidîn'in annesinin Yezdicerd'in kızı Şâhzenân/Şehrbânû olduğunu kaydetmekte ${ }^{38}$ ve Şehrbânû'nun Hz. Ömer döneminde Medine'ye getirilmesiyle ilgili 5. imâm Muhammed Bâkır'dan gelen rivayetin detaylarına yer vermektedir: Medine kızları Şehrbânû'nun güzelliğini seyretmek için toplaşmış; Hz. Ömer yüzünü görmek istediği zaman Şehrbânû yüzünü kapayarak halifenin gazabına neden olmuş; Hz. Ali Şehrbânû'nun serbest bırakılmasını ve kendisine eş

${ }^{34}$ Kâșifî, Ravzatü'ș-şühedâ, 623.

${ }^{35}$ Kâşifî, Ravzatü'ş-şühedâ, 623.

${ }^{36}$ Kâșifî, Ravzatü's-sühedâ, 713-716.

${ }^{37}$ Kâş̧îi, Ravzatü'ş-şühedâ, 715.

${ }^{38}$ Muhammed Bâkır b. Muhammed Takî el-Meclisî, Cilâu'l-'uyûn, thk. Seyyid Alî İmâmyân (Kum: yy. ty.), 826. 
seçmesine müsaade edilmesini sağlamış; Şehrbânû'nun Hz. Hüseyin'i seçmesi üzerine Hz. Ali oğlunu "bu kadın sana dünyanın en hayırlısını doğuracaktır" sözleriyle müjdelemiştir. ${ }^{39}$

Annesinin Ali b. Hüseyin'i doğururken vefat ettiğini belirten Meclisî, babasının vefatından sonra onun kendi annesini evlendirdiğine dair rivayetleri doğru bulmamaktadır. ${ }^{40}$ Şehrbânû'nun Hz. Ali veya Hz. Osman döneminde esir edildiğine dair rivayetlere de değinen Meclisî, Zeynelâbidîn'in annesiyle ilgili çelişkili rivayetleri değerlendirirken iki farklı rivayetten birisinin ravisinin muhtemelen yanılgıya düştüğünü, dolayısıyla Yezdicerd'in kızının Hz. Ömer döneminde esir edildiğine dair 5. imâm Bâkır'dan gelen rivayetin doğru olduğunu kabul etmektedir. ${ }^{41}$

Diğer taraftan Meclisî daha önce Arapça maktellerde rastlanmayan, Kâşifînnin de bahsetmediği bir hususa, müslümanlar tarafından esir edilmeden önce Şehrbânû'nun Hz. Peygamber, Hz. Fâtıma ve Hz. Hüseyin'le rüya aracılığıyla görüștügüne dair rivayete yer vermektedir: Müslümanların Sâsânî fetihleri sırasında Şehrbânû bir rüyâ görmüş, bu rüyâda $\mathrm{Hz}$. Peygamber kendisini Hz. Hüseyin'le nikahlamış, o günden sonra imâmet semasının güneşinin sevgisi kalbine dolmuştur. Yine Şehribânû'nun rüyasında gördüğü ve telkiniyle müslüman olduğu Hz. Fâtımâ, kısa zamanda babasının müslümanlara yenileceğini, kendisinin esir alınacağını haber vermiş ve Allah'ın koruması altında dokunulmadan Hz. Hüseyin'e ulaşacağını vadetmiştir. Medine'ye ilahî koruma altında ulaşan Şehrbânû, Hz. Peygamber'in rüya aracıllğıyla kendisiyle tanıştırdığı Hz. Hüseyin'i eş olarak seçmiştir. ${ }^{42}$ Kâş̧ifî gibi Meclisî de Şehrbânû sayesinde Allah'ın Arap ve Acem'den seçtiği Hâşimoğulları ve Farslar arasında kurulan nikahın önemini vurgulamakta ve bu sebepten Zeynelâbidîn'in “İbnü’l-hiyarateyn” olarak adlandırıldığını kaydetmektedir. ${ }^{43}$

Şüphesiz her iki Farsça maktelde millî kimlik unsuru olarak Şehrbânû'yla ilgili üzerinde durulan en önemli ortak nokta, Farsların seçilmişliği konusudur. Şehrbânû'nun Hz. Hüseyin'le evliliği Arabın en faziletlisi olan Benî Hâşim'le Acemin en faziletlisi olan Farsları birleştirmiştir. Meclisî'nin maktelinde özellikle Şehrbânû'ya karşı tutumu açısından $\mathrm{Hz}$. Ömer-Hz. Ali karşıtlığı dikkat çekmektedir. Amir-Moezzi'nin de vurguladı ̆̆ gibi, 5. imâm Bâkır'a nisbet edilen bu rivayette Kisrâ Yezdicerd'in kızına karşı

\footnotetext{
${ }^{39}$ Meclisî, Cilâu'l-'uyûn, 827. Krş. Saffâr Kummî, Besâirü'd-derecât, 1:593-594

${ }^{40}$ Meclisî, Cilâu'l-'uyûn, 831-833.

${ }^{41}$ Meclisî, Cilâu'l-'uyûn, 832.

42 Meclisî, Cilâu'l-'uyûn, 833.

${ }^{43}$ Meclisî, Cilâu'l-'uyûn, 827.
} 
tavrı bakımından ortaya konan Hz. Ömer ve Hz. Ali imajı, ayrıca Şehrbânû'nun doğacak olan imâmın annesi olacağının Hz. Ali tarafından müjdelenmesi gibi, özellikle Şî̂ Farslar için millî-dinî açıdan önem arzeden başlıca hususlar ${ }^{44}$ bulunmaktadır. Ravzatü'ş-şühedâ'dan farklı olarak Cilâu'l'uyûn'da, Sâsânî prensesinin itaatsizliğine ve anlamını bilmediği Farsça sözlere kızarak onu cezalandırmak isteyen Hz. Ömer'in aksine Şehrbânû'yu kollayan, "Anlamını bilmediğin sözlerin seni aşağıladığını nasıl anladın?" sözleriyle halifeye Farsça anlamadığını söylerken Şehrbânû'yla Farsça diyalog kurması özellikle vurgulanan Hz. Ali ${ }^{45}$ karşı taraflar olarak gösterilmektedir.

\section{Türkçe Maktellerde Şehrbânû: Makteli Destanlaştırıcı Unsur}

Türkçe makteller üzerine çalışmalarıyla bilinen Kenan Özçelik manzum veya mensur olmalarına bakılmaksızın olay kurgusu ve anlatım özellikleri açısından Türkçe maktelleri iki başlıca gruba ayırmaktadır: 1) İlk Türkçe maktel olarak bilinen Yûsuf-ı Meddâh'ın etkisiyle yazılanlar; 2) Kâşifînnin Ravzatü'ş-Şühedồ'sının çevirileri. ${ }^{46}$ Kanaatimizce genel anlamda birinci grup maktellerle ortak birtakım özellikler taşımakla birlikte, özellikle olay kurgusunda Şehrbânû'yla ilgili veriler açısından Türkçe maktellerin üçüncü bir grubu da bulunmaktadır. Üç maktel grubu konu açısından analiz edilmeden önce, Kerbelâ olayını tarihî kaynaklara en yakın şekliyle ele alan bir Türkçe maktel olarak bilinen ${ }^{47}$ Lâmiî Çelebi'nin (ö. 938/1532) maktelinde sadece bir defa ve dolaylı bir şekilde Şehrbânû'dan sözedildiği için bahsi geçen makteli Tablo 1'e dahil etmediğimizi belirtilmeliyiz. ${ }^{48}$

Türkçe ilk maktel olarak bilinen Yûsuf-ı Meddâh'ın (XIV. yy.) Maktel-i Hüseyn'i ile benzer olay kurgusuna sahip birinci grup maktellerde Sâsânî prensesi Şehrbânû'yla ilgili veriler iki kategoride değerlendirilebilir: 1) Kerbelâ'ya katılmış Ehl-i Beyt kadınlarından birisi olarak kendisinden bahseden olaylar; 2) Bizzat kendisiyle ilgili olaylar. Birinci kategorideki bilgiler Şehrbânû'nun Kâsım b. Hasan'ın savaş meydanına çıktığı zaman

\footnotetext{
${ }^{44}$ Amir-Moezzi, "Shahrbānū”, 515.

45 Hz. Ali ile Şehrbânû arasında geçen kısa diyalogda Hz. Ali'nin Sâsânî prensesiyle Farsça konuştuğunu iki ayrı yerde vurgulanmaktadır. Bkz. Meclisî, Cilâu'l-'uyûn, 832-833.

46 Özçelik, Lâmiî Celebî’nin makteli gibi bu iki grup dıșında kalan maktel örneğinin de bulunduğunu belirtmektedir. Kenan Özçelik, "Lâmiî Çelebi'nin Kitâb-ı Maktel-i Âl-i Resûl'ü”, Bursalı Lâmiî Çelebi ve Dönemi, ed. Bilal Kimekli, Süleyman Eroğlu, (Bursa: Bursa Büyükşehir Belediyesi, 2011), 274.

47 Ertuğrul Ertekin, “Arapça, Farsça ve Türkçe Maktel-i Hüseyinler”, 98; Serkan Türkoğlu, "Türk Edebiyatında Maktel-i Hüseyinler ve Bekâî'nin Kitâb-ı Kerbelâ Mesnevisi”, Türkiyat Araştırmaları Enstitüsü Dergisi, 58(2017): 110.

${ }^{48}$ Lâmiî Çelebi, sadece Kerbelâ sonrası yaşanan olağanüstü olaylar çerçevesinde zikrettiği “Deveci olayı" bağlamında Şehrbânû'nun Hz. Hüseyin'le evliliğine işaret etmektedir. Lâmiî Çelebî, Maktel-i Âli Resûl, thk. Ertuğrul Ertekin (İstanbul: Kevser Yayınları, 2012), 129.
} 
Tablo 1: Türkçe Maktellerin Olay Kurgusunda Şehrbânû

\begin{tabular}{|c|c|c|c|c|c|c|c|c|c|c|c|}
\hline \multirow{2}{*}{$\begin{array}{l}\text { Müellif } \\
\text { Șehrbânû'yla } \\
\text { ilgili olaylar }\end{array}$} & \multicolumn{5}{|c|}{ I. grup } & \multicolumn{4}{|c|}{ II. grup } & \multicolumn{2}{|c|}{ III. grup } \\
\hline & 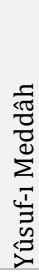 & 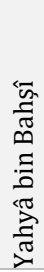 & 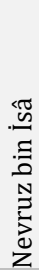 & 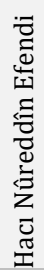 & 㑊 & 茎 & 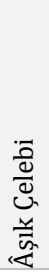 & 范 & 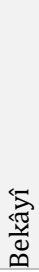 & 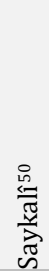 & 点 \\
\hline $\begin{array}{l}\text { Hz. Ömer'in } \\
\text { hilafetinde ordu } \\
\text { kumandanı Hz. } \\
\text { Ali'nin Kisrâ } \\
\text { hükümdarını } \\
\text { katletmesi, } \\
\text { Şehrbânû'yu } \\
\text { birer erkek ve } \\
\text { kıkardeşiyle } \\
\text { esir alması }\end{array}$ & & & & & & & & & & $\mathbf{X}$ & $\mathbf{X}$ \\
\hline $\begin{array}{l}\text { Hz. Ömer'in } \\
\text { Şehrbânû'nun } \\
\text { İslâm'ı kabul } \\
\text { etmeyen erkek } \\
\text { kardeşini } \\
\text { öldürmesi, Hz. } \\
\text { Ali'nin } \\
\text { tavsiyesiyle } \\
\text { Şehrbânû'ya ve } \\
\text { kızkardeşine } \\
\text { süre tanınması }\end{array}$ & & & & & & & & & & $\mathbf{X}$ & $\mathbf{X}$ \\
\hline $\begin{array}{l}\text { Şehrbânû'nun } \\
\text { diğer adaylar } \\
\text { arasından Hz. } \\
\text { Hüseyin'i eş } \\
\text { olarak seçmesi }\end{array}$ & & & & & & & & & & $\mathbf{X}$ & $\mathbf{X}$ \\
\hline $\begin{array}{l}\text { Hz. Ömer'in } \\
\text { Şehrbânû'yla Hz. } \\
\text { Hüseyin'in } \\
\text { nikahını kıyması }\end{array}$ & & & & & & & & & & $\mathbf{X}$ & \\
\hline
\end{tabular}

${ }^{49}$ Zühre Değirmenci, Der Beyân-i Sergüzeșt-i İmâm Hüseyin (Çanakkale: Onsekiz Mart Üniversitesi, SBE, Yüksek Lisans Tezi, Çanakkale 2009).

50 Makalede Saykalî'nin Ravzatü'ş-şühedồ'sının 1-236. varaklarından yararlanılmış (Saykalî, Ravzatü'ş-şühedâ: İnceleme - metin - dizin: I. bölüm 1-236, thk. Talip Yıldırım, (İstanbul: Bilgeoğuz Yayınları, 2016)), bu varakların dıșındaki kısma tekâbül eden olayların karșılı̆̆ı için "?" ișaresi kullanılmıştır (Eserin yazma nüshalarına ulaşılamadığı için ilgili kısma değişiklik yapılamamış̦ır.)

${ }^{51}$ Mehmet Altunmeral vd., "Bir Maktel-i Hüseyn Örneği". Sûfi Araştırmaları - Sufi Studies, 1 (1) (2010): 61-105. 


\begin{tabular}{|c|c|c|c|c|c|c|}
\hline $\begin{array}{l}\text { Şehrbânû'nun } \\
\text { kıkkardeşinin } \\
\text { Hz. Ebû Bekir'in } \\
\text { oğluyla } \\
\text { evlendirilmesi }\end{array}$ & & & & & & $\mathbf{X}$ \\
\hline $\begin{array}{l}\text { Şehrbânû'nun } \\
\text { Hz. Hüseyin'i eş } \\
\text { olarak } \\
\text { seçmesinin } \\
\text { Yezîd'in Kerbelâ } \\
\text { olayına kadar } \\
\text { sürecekdüşmanl } \\
\text { ığına sebep } \\
\text { olması }\end{array}$ & & & & & & $\mathbf{X}$ \\
\hline $\begin{array}{l}\text { Şehrbânû'nun } \\
\text { Hz. Hüseyin'le } \\
\text { evlenirken } \quad 100 \\
\text { kenizesi } \\
\text { bulunduğu, } 50 \\
\text { kenizeyi düğün } \\
\text { gecesi, } \quad 40 \\
\text { kenizeyi oğlu } \\
\text { Zeynelâbidîn } \\
\text { doğduğunda, } \\
\text { Şîrîn isimli } \\
\text { kenizeyi ise Hz. } \\
\text { Hüseyin } \\
\text { beğendiği için } \\
\text { azad etmesi }\end{array}$ & & $\mathbf{X}$ & $\mathbf{X}$ & $\mathbf{X}$ & $\mathbf{X}^{52}$ & \\
\hline $\begin{array}{l}\text { Hz. Ali ve Hz. } \\
\text { Hasan'ın } \\
\text { vefatına ağlayan } \\
\text { Ehl-i Beyt } \\
\text { kadınları } \\
\text { arasında } \\
\text { Șehrbânû ve Hz. } \\
\text { Âisşe'nin de } \\
\text { bulunması }\end{array}$ & $\mathbf{X}$ & & & & & \\
\hline $\begin{array}{l}\text { Kerbelâ'da } \\
\text { konakladıkların } \\
\text { da Hz. } \\
\text { Hüseyin'in } \\
\text { Şehrbânû'ya } \\
\text { kendisinden } \\
\text { sonra feryâd u }\end{array}$ & & $\mathbf{X}$ & $\mathbf{X}$ & $\mathbf{X}$ & $\mathbf{X}$ & \\
\hline
\end{tabular}

52 Şehrbânû'nun oğlu Zeynelâbidîn'in beğenisi üzerine Şîîin'i azad etmesinden bahsedilmektedir. Hulusi Eren, Dârendeli Kâtipzâde Bekâŷ̂-Maktel-i Hüseyn: İnceleme-Tenkitli Metin-Sözlük Dizin (Ankara: Hacettepe Üniversitesi, SBE, Yüksek Lisans Tezi, 2014), 580-581. 
Elnura AZİZOVA

\begin{tabular}{|c|c|c|c|c|c|c|c|}
\hline $\begin{array}{l}\text { figân } \\
\text { etmemesini } \\
\text { tavsiyesi }\end{array}$ & & & & & & & \\
\hline $\begin{array}{l}\text { Kâsım b. Hasan } \\
\text { Kerbelâ'da savaş } \\
\text { meydanına } \\
\text { girdiğinde diğer } \\
\text { Ehl-i Beyt } \\
\text { kadınlarıyla } \\
\text { birlikte } \\
\text { Şehrbânû'nun da } \\
\text { ağlaması }\end{array}$ & $\mathbf{X}$ & & $\mathbf{X}$ & & & & \\
\hline $\begin{array}{l}\text { Büyük oğlu Ali b. } \\
\text { Hüseyin savaş } \\
\text { meydanına } \\
\text { girdiğinde } \\
\text { Şehrbânû'nun } \\
\text { ağlaması }\end{array}$ & $\mathbf{X}$ & & & & & & \\
\hline $\begin{array}{l}\text { Kerbelâ'da } \\
\text { Şehrbânû'nun } \\
\text { küçük oğlunun } \\
\text { ağzından okla } \\
\text { vurulması }\end{array}$ & & $\mathbf{X}$ & $\mathbf{X}$ & & & & \\
\hline $\begin{array}{l}\text { Kerbelâ'da } \\
\text { Şehrbânû'nun } \\
\text { Hz. Hüseyin'e } \\
\text { çocuklarını kime } \\
\text { emanet ettiğini } \\
\text { sorması }\end{array}$ & & & & $\mathbf{X}$ & & $\mathbf{X}$ & $\mathbf{X}$ \\
\hline $\begin{array}{l}\text { Hz. Hüseyin } \\
\text { savaş meydanına } \\
\text { gitmeden önce } \\
\text { Şehrbânû'nun } \\
\text { kendi akıbetiyle } \\
\text { ilgili endişesini } \\
\text { bildirmesi, Hz. } \\
\text { Hüseyin'in } \\
\text { kendisine bir } \\
\text { zarar } \\
\text { dokunmayacağı } \\
\text { nı vadetmesi }\end{array}$ & & & & $\mathbf{X}$ & $\mathbf{X}$ & $\mathbf{X}$ & $\mathbf{X}$ \\
\hline
\end{tabular}




\begin{tabular}{|c|c|c|c|c|c|c|c|c|c|c|}
\hline $\begin{array}{l}\text { Hz. Hüseyin'in } \\
\text { şehîd } \\
\text { edilmesinin } \\
\text { ardından } \\
\text { çadırların önüne } \\
\text { gelen atına } \\
\text { Şehrbânû'nun } \\
\text { hitabı }\end{array}$ & & & & & & $*_{53}$ & $*_{54}$ & & $\mathbf{X}$ & \\
\hline $\begin{array}{l}\text { Kerbelâ sonrası } \\
\text { çadırların } \\
\text { yağmalanması } \\
\text { sırasında Hz. } \\
\text { Hüseyin'in } \\
\text { hatunu olarak } \\
\text { Şehrbânû'nun iki } \\
\text { kızı ve oğluyla } \\
\text { zikredilmesi }\end{array}$ & $\mathbf{X}$ & $\mathbf{X}$ & & $X^{55}$ & & & & & & $?$ \\
\hline $\begin{array}{l}\text { Kûfe'ye başı açık } \\
\text { götürülen } \\
\text { Kerbelâ } \\
\text { kadınları } \\
\text { arasında } \\
\text { Şehrbânû'nun da } \\
\text { bulunması }\end{array}$ & $\mathbf{X}$ & $\mathbf{X}$ & & & & & & & & \\
\hline $\begin{array}{l}\text { Halep } \\
\text { yakınlarında } \\
\text { Şehrbânû'nun } \\
\text { bir erkek çocuk } \\
\text { doğurması, } \\
\text { Muhsin/Muhassi } \\
\text { n isimli bu } \\
\text { çocuğun vefat } \\
\text { etmesi, } \\
\text { mezarının } \\
\text { meşhed olarak } \\
\text { ziyaret edilmesi }\end{array}$ & $\mathbf{X}$ & & $\mathbf{X}$ & $\mathbf{X}$ & $\mathbf{X}$ & & & & & \\
\hline $\begin{array}{l}\text { Halep } \\
\text { yakınlarında } \\
\text { Şehrbânû'nun }\end{array}$ & & & & & & $\mathbf{X}$ & $\mathbf{X}$ & $\mathbf{X}$ & $\mathbf{X}$ & \\
\hline
\end{tabular}

53 Fuzûlî’nin maktelinde aynı olayda özel olarak Șehrbânû'dan değil, genel olarak Ehl-i Beyt kadınlarından ("mutahharât-ı Ehl-i Beyt") bahsedilmektedir (Şeymâ Güngör, Fuzulî: Hadikatü'sSü'eda (Ankara: Kültür ve Turizm Bakanlı̆̆ı Yayınları, 1987), 431).

54 Âșık Çelebi de özel olarak Şehrbânû'dan değil, Ehl-i Beyt kadınlarından ("A'yân-i ehl-i Harem-i Muhterem") bahsetmektedir. Kenan Özçelik, Aşılk Çelebi: Ravzatü'ş-şühedâ tercümesi: İnceleme metin (İstanbul: Doğu Kütüphanesi, 2016), 423.

55 Oğlundan bahsedilmemektedir. Hacı Nûreddîn Efendi, Maktel-i Hüseyin, haz. Mehmet Karaarslan (İstanbul: Önsöz Yayıncllık, 2012), 95.

${ }^{56}$ Oğlundan bahsedilmektedir. Altunmeral vd., "Bir makteli Hüseyn Örneği", 91-92. 


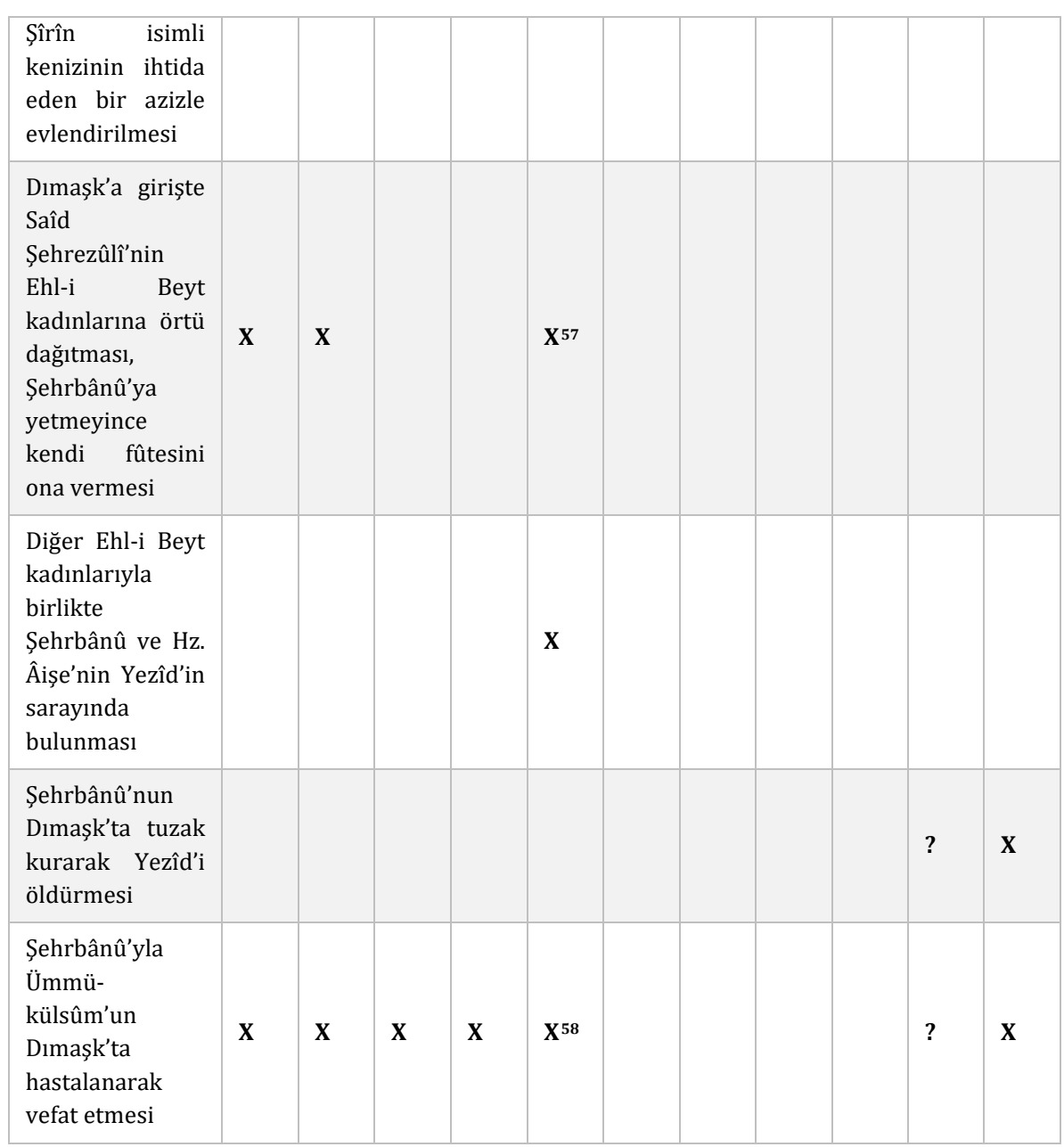

ağlaması, Dımaşk'a başı-boynu açık şekilde götürülen Ehl-i Beyt kadınları arasında zikredilmesi gibi hususlardır. Saîd Şehrezûlî isimli bir sünnî bezirganın, başı açık şekilde Dımaşk'a getirilen Ehl-i Beyt kadınlarına kendi tülbentini yırtarak örtü yapması, Şehrbânû'ya yetmediği için üzerindeki futeyi kendisine vermesi ${ }^{59}$ yine bu kategoride değerlendirilebilecek, aynı zamanda Ehl-i Beyt kadınları arasında kendisiyle ilgili bir ayrıcalık olarak da

${ }^{57}$ Şehrbânû'ya yetmediğinden bahsedilmemektedir. Değirmenci, Der Beyân-i, 78-79.

${ }^{58}$ Şehrbânû ve Ümmü Gülsüm'le birlikte Rukiye'nin de Dımașk'ta vefat ettiği kaydedilir. Değirmenci, Der Beyân-i, 83.

${ }^{59} \mathrm{Krss.} \mathrm{Hz}$. Hüseyin'i seçen Șehrbânûyya Hz. Ali'nin kendi cüppesini örtü yapmasıyla ilgili rivayet (Beyhakî, Lübâbü'l-ensâb, 1/346-347). 
görülebilecek bir husustur.60 Medine'ye dönmeden önce Şehrbânû'nun Ümmü-külsûm'la birlikte Dımaşk'ta vefat etmesi61 de ölümüyle Ehl-i Beyt kadınlarıyla ortak bir kaderi paylaştığı şeklinde yorumlanabilecek bir diğer detaydır.

Birinci grup maktellerde Șehrbânû'nun bizzat kendisiyle ilgili bilgiler ise Hz. Hüseyin'in hanımı ve çocuklarının annesi olması bağlamındadır. Detaylarında bazı farklılıklar bulunmakla birlikte maktellerde "büyük oğlu" Ali b. Hüseyin savaş meydanına çıktığı zaman onu vazgeçirmeye çalışan, küçük oğlu ağzından vurularak katledilen, Kerbelâ sonrası çadırların yağmalanması sırasında iki kızıyla birlikte ağlayan ve "küçük oğlunu" eteğiyle gizleyen, Halep yakınlarında bir erkek çocuk doğuran ve Muhsin/Muhassin isimli bu bebeği orada ölen Şehrbânû, Hz. Hüseyin'in eşi ve büyüklü-küçüklü çocuklarının annesi olarak kendisinden sıkça sözedilen kadındır. ${ }^{62}$

Tablo 1 ve Tablo 2'den de anlaşılacağı üzere Ravzatü'ş-şühedâ'nın çevirisi olan ${ }^{63}$ veya çevirisinin etkisinde kaleme alınan ikinci grup Türkçe maktellerde Şehrbânû'yla ilgili olaylar kurgu açısından Kâşifî'nin makteline paralellik arzetmektedir. ${ }^{64}$ Bununla birlikte ikinci grup Türkçe maktellerde, konuyla ilgili kaynak metnin orijinalinden farklı bir husus dikkat çekmektedir. Hacim olarak küçük olmasına rağmen maktelin okunduğu toplumun millı̂ kimliğiyle ilgili büyük önem arzeden bu farklılık, Kisrâ Yezdicerd'in kızı Şehrbânû'nun Hz. Hüseyin'le evlenmesi sonucunda Ali b.

60 Kenan Özçelik, Yûsuf-ı Meddâh ve Maktel-i Hüseyn: Inceleme - Metin - Sözlük (Ankara: Ankara Üniversitesi, SBE, Yüksek Lisans Tezi, 2008), 273, 290-292; Mehmet Akif Gülsüm, Yahyâ Bin Bahşînnin Maktel-i Hüseyin adll mesnevisi: İnceleme ve metin (Kırklareli: Kırklareli Üniversitesi, SBE, Yüksek Lisans Tezi, 2019), 168-169; Yüksel, Nevruz Bin İsa'nın Manzume-i Kıssa-i Kerbelası: Varak 70a-139b (Ordu: Ordu Üniversitesi, SBE, Yüksek Lisans Tezi, 2012), 94, 102; 123-124; Değirmenci, Der Beyân$i, 64,77$.

61 Özçelik, Yûsuf-ı Meddâh, 323; Gülsüm, Yahyâ Bin Bahşî, 181-182; Hacı Nûreddîn Efendi, Maktel-i Hüseyin, 121; Yüksel, Nevruz Bin İsa, 145; Değirmenci, Der Beyân-i, 83.

62 Özçelik, Yûsuf-ı Meddâh, 260-261, 289; Hacı Nûreddîn Efendi, Maktel-i Hüseyin, 96, 108; Değirmenci, Der Beyân-i, 77-78; Gülsüm, Yahyâ Bin Bahșî, 140; Yüksel, Nevruz Bin İsa, 122.

${ }^{63}$ Kenan Özçelik, Kâşifî̀nin Ravzatü'ş-şühedâ'sının birbirine yakın zamanlarda yapılmış üç tercümesi olduğunu belirtmektedir: Âşık Çelebi (953/1546), Fuzûlî (yaklaşık olarak 954/1547) ve Câmî-i Mısrî (960/1553) çevirileri (Özçelik, Âşık Çelebi, 24-25). Ravzatü'ş-şühedâ'nın daha erken çevirisi Muhammed bin Hüseyin Kâtib Nişâtî tarafından Şühedânâme ismiyle 945/1539 senesinde Safevî şahı Tahmasb'ın (1524-1576) isteği üzerine Şiraz şehrinde yapılmıştır. Şühedânâme'nin dil özellikleri üzerine yaptığı doktora çalışmasında Möhsün Nağısoylu'nun kaydettiğine göre, eserin bilinen tek nüshası M-259/13659 katalog numarasıyla Azerbaycan Millî İlimler Akademisi'nin Yazmalar Enstitüsü'nde kayıtlıdır (Möhsün Nağısoylu, Seçilmiş Әsarlari (Bakı: Elm, 2017), 2: 12). Henüz yayınlanmamış Şühedânâme'nin yazma nüshasından yararlanamadığımız için eser, Tablo 1 ve Tablo 2'ye dahil edilmemiștir.

${ }^{64}$ Güngör, Hadîkatü's-süedâ, 325, 347, 424, 450, 451, 452; Câmi-i Rûmî (Mısrî), Sa'âdetnâme (Milllet, Ali Emiri Trh., 000326), 289a, 305a, 359b, 381a-383a; Özçelik, Aşı Çelebi, 370, 469-470, 490-492; Eren, Dârendeli Kâtipzâde Bekâyî, 309-310, 353-354, 532, 580-581, 586. 
Hüseyin'in "peygamberlikle melikliği birleştirdiği"ne dair Kâşifînnin Ravzatü'ş-şühedâ'daki yaklaşımının ${ }^{65}$ ikinci grup Türkçe maktellerde bulunmamasıdır. Kâşifî bu hususu eserinin Kerbelâ olayıyla ilgili kısmında değil, on iki imâmın biyografisinden de bahsettiği hâtime kısmında Ali b. Hüseyin Zeynelâbidîn'den söz ederken aktarmaktadır. Çeviri özelliği açısından orijinal metne yakın olmakla birlikte Ravzatü'ş-Şühedâ'nın bilinen en erken Türkçe çevirisi olan Nişâtînnin Şühedânâme'sinde hâtime kısmı bulunmamaktadır. 66 Âşık Çelebi'nin Ravzatü'ş-şühedâ çevirisinde de hâtime kısmı bulunmayıp, eser onuncu fasıldan sonra kısa bir münacatla tamamlanmaktadır. ${ }^{67}$ Dârendeli Kâtipzâde Bekâyî̀nin Maktel-i Hüseyn'i de Kerbelâ yolcularının Medine'ye dönmesiyle ilgili bilgilerin ardından Bekâyînnin nazm tarihine dair mısralarıyla tamamlanmakta68; Câmî-i Rûmînnin Saâdetnâme isimli Ravzatü'ş-şühedâ tercümesi on bâbdan oluşup, Ehl-i Beyt'in Şam yolculuğu da onuncu bâba dahil edilmiş, özel olarak on iki imam hakkında bilgi ve duadan oluşan hâtime kısmı bulunmamaktadır. ${ }^{69}$ Dolayısıyla, Fuzûlînnin Hadîkatü's-süedâ'sı istisna edilirse, ikinci grup Türkçe maktellerde Kâşifînin maktelindeki gibi on iki imâmdan bahseden hâtime kısmına rastlanmamaktadır. Fuzûlî ise Hadikatü's-süedâ'sının hatime kısmında on iki imamın biyografisiyle ilgili altbaşlıkta 4. imâm Zeynelâbidîn'le ilgili bilgileri onun doğum ve vefat tarihleri, çocuklarının sayısıyla sınırlı tutmuş, annesinden ve onun sayesinde peygamberlikle melikliğin birleştirilmesi gibi önemli bir husustan bahsetmemiştir. ${ }^{70}$

Aktarılanlarla ilgili Tablo 2'den de görüldüğü gibi Kâşifî’nin maktelinin hâtime kısmında "Kisrâ Yezdicerd b. Şîrûye b. Pervîz b. Hürmüz b. Nûşîravân el-Melik el-'Âdil”in kızı olarak Hz. Hüseyin'le evliliği sebebiyle peygamberlikle melikliği birleştiren, sadece Hz. Hüseyin'in değil, Hz. Hasan'ın da soyunun peygamberlikle melikliği birleștirmesine vesile olan, böylece İslam Peygamberi'nin her iki torunundan soyunu Sâsânî

${ }^{65}$ Kâşifî, Ravzatü'ş-şühedâ, 715.

${ }^{66}$ Nağısoylu, bunun sebebinin Nişâtî'nin çeviri için aldığı kaynak nüsha özelliğiyle ilişkilendirmekte ve Azerbaycan Millî İlimler Akademisi'nin Yazmalar Enstitüsü'nde bulunan Ravzatü'ş-şühedâ yazmalarının sadece birinde hâtime kısmının bulunmasını argüman olarak göstermektedir. Nağısoylu, Seçilmiş Әsarlari, 2: 67.

67 Özçelik, Âşık Çelebi, 511-512. Özçelik, Kâşifî’nin Ravzatü'ş-şühedâ'da genel kabul görmüş Ehl-i Sünnet mezhebinin görüşlerine karşı herhangi bir olumsuz bakış açısı ortaya koymamakla birlikte, Şîa mezhebinin bakış açısını yansıtan ifadeleri olduğuna; bir Osmanlı kadısı olarak Âşık Çelebi'nin ilgili kısımları tercüme etmediğine dair örnekler vermektedir. Bkz. Özçelik, Âşıl Çelebi, 76-78. Ayrıca, Âşık Çelebi'nin on iki imâmdan bahseden hatime kısmını, kaynak metnin kullanılan nüshasında bu kısmın olmaması ihtimali bir yana bırakılırsa, aynı anlayış çerçevesinde çevirmediği düşünülebilir. ${ }^{68}$ Eren, Dârendeli Kâtipzâde Bekâyî, 602-603.

|226| $\quad{ }^{69}$ Krş. Cihan Okuyucu, “Câmî-i Rûmî (Mırrî) ve Sa’âdetnâme’si”, Türkiyat Mecmuası21 (2011): 304305.

${ }^{70}$ Güngör, Hadikatü's-süedâ, 484. 
Tablo 2: Şehrbânû'yla ilgili veriler açısından Kâşifînin Ravzatü'ş-Şühedâ'sıyla Türkçe Çevirilerinin Karșılaștırılması

\begin{tabular}{|c|c|c|c|c|c|}
\hline $\begin{array}{l}\text { Müellif } \\
\text { Olay }\end{array}$ & 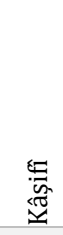 & 纽 & $\begin{array}{l}\overrightarrow{0} \\
\frac{0}{0} \\
\frac{n}{\omega} \\
\bar{a}\end{array}$ & 范 & 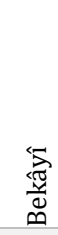 \\
\hline $\begin{array}{l}\text { Șehrbânû sayesinde peygamberlikle melikliğin } \\
\text { birleştirilmesi }\end{array}$ & $X$ & & & & \\
\hline $\begin{array}{l}\text { Şehrbânû'nun Hz. Hüseyin'le evliliği, İmâm } \\
\text { Zeynelâbidîn'in doğumu }\end{array}$ & $X$ & $X$ & $X$ & $X$ & $X$ \\
\hline $\begin{array}{l}\text { Hz. Hüseyin'in Kerbelâ'da konakladıkları zaman şehîd } \\
\text { edilmesi durumunda dövünmemesi için Şehrbânû'yu } \\
\text { uyarması }\end{array}$ & $\mathrm{X}$ & $\mathrm{X}$ & $\mathrm{X}$ & $X$ & $X$ \\
\hline $\begin{array}{l}\text { Kerbelâ'da Şehrbânû'nun garip olduğu için Hz. } \\
\text { Hüseyin'e kendisinden sonra nasıl yaşayacağına dair } \\
\text { serzenişi }\end{array}$ & $X$ & $X$ & $X$ & $X$ & $X$ \\
\hline $\begin{array}{l}\text { Dımaşk yolculuğu sırasında Halep yakınlarında } \\
\text { Şehrbânû'yla Zeynelâbidîn'in Şîrîn'i müslüman olmuş } \\
\text { bir azîzle evlendirmeleri }\end{array}$ & $X$ & $X$ & $X$ & $\mathrm{X}$ & $X$ \\
\hline $\begin{array}{l}\text { Şehrbânû'nun Dımaşk yolculuğunda Ehl-i Beyt'in } \\
\text { yanında bulunması }\end{array}$ & $X$ & $X$ & $X$ & $X$ & $X$ \\
\hline
\end{tabular}

hanedanının varisi olarak devam ettiren, Fars kimliğiyle ön plana çıkarılmış bir Şehrbânû imajına Ravzatü'ş-şühedâ'nın Türkçe çevirilerinde rastlanmamaktadır. Kâşifi'nin Şehrbânû'dan bahsettiği neredeyse bütün olayların ikinci grup Türkçe maktellerde bulunmasına karşıllk, Ravzatü'şşühedâ'nın hâtime kısmında bulunan Şehrbânû'yla ilgili böylesine önemli bir hususun müellifler/mütercimler tarafından fark edilmemesi olasıllı̆ı azdır. Bu husus, Nişâtînnin Şühedânâme'siyle ilgili Möhsün Nağısoylu'nun ifade ettiği gibi tercüme için kullanılan nüshaya bağlı bir durum ile ${ }^{71}$ veya Âşı Çelebi'nin Ravzatü'ş-şühedâ Tercümesi'nde mezhep hassasiyetiyle ilgili konulardan verdiği örneklerle Kenan Özçelik'in belirttiği gibi kaynak metnin yazarıyla Türkçe'ye çeviren müellifin dinî temayüllerindeki farklılıklarla ${ }^{72}$ açıklanabilir. Fakat, Hadîkatü's-süedâ' da görüldüğü gibi çeviri için esas alınan Farsça nüshada bulunan hâtimenin on iki imamla ilgili kısmı Türkçe'ye aktarlırken, genel olarak Şehrbânû'dan, özellikle onun bu önemli

\footnotetext{
${ }^{71}$ Nağısoylu, Seçilmiş Әsarlari, 2: 67.

${ }^{72}$ Özçelik, Âşık Çelebi, 76-78.
} 
misyonundan bahsedilmemesinin başlıca sebebi, eserin Türk toplumunda okunmak üzere tercüme/telif edilmiş olmasıdır. Bu husus çoğunlukla XVI. yüzyıl Osmanlı-Safevî sahasında yapılmış bu çevirilerin muhataplarının yönetim ve toplum olarak Türk-Müslüman kimliğine sahip olmalarıyla açıklanabilir. Bunu destekleyen bir diğer maktel örneği olarak XIX. yüzyıl Azerbaycan alimi Abbaskulu Ağa Bakühanlı'nın Riyâzü'l-Kuds'ü gösterilebilir. Meclisînnin Cilâu'l-'uyûn'unun özet çevirisi olan bu maktelde Ali b. Hüseyin Zeynelâbidîn'den bahsedilirken, Şehrbânû'yla ilgili kaynak metinde verilen geniş bilgiler "Yezdicerd-i pâdişâh-ı Acemin kızıdır, bazıları Şâhzenân demişler" şeklinde özetlenmiş, annesi sebebiyle Zeynelâbidîn'in "İbnü'l-hiyarateyn" olmasından da bahsedilmemiştir.73

Tablo 1'de Sabir Saykalî’nin (ö. 1212/1797) Ravzatü'ş-şühedầsı ve anonim bir Türkçe maktelle örneklendirilen üçüncü grup Türkçe makteller, Şehrbânû'yla ilgili bazı veriler açısından birinci grup maktellere paralellik arzetmekle birlikte, içerik ve olay kurgusuna göre ilk iki gruptan farklıdır. Konu açısından başlıca fark Şehrbânû'nun eş adayları arasındaki tercihinin, Yezîd b. Muâviye'nin Hz. Hüseyin'e karşı adâvetine sebep olduğu şeklinde destansı olay kurgusu üzerinden anlatılmasıdır. Hz. Ömer döneminde Şehrbânû'nun esir olarak Medîne'ye getirildiğine dair 5. imâm Bâkır'a nisbet edilen rivayete bazı destansı unsurlar eklenmekle oluşturulmuş bu anlatıda olaylar şöyle gelişmektedir: Halifeliği döneminde Hz. Ömer'in Sâsânî üzerine gönderdiği ordu kumandanı Hz. Ali Kisrâ'yı yenmiş, Hürmüz adlı oğlunu, Şehrbânû ve Nâznûş/Mâriyûse isimli kızlarını esir olarak Medine'ye getirmiştir. Hz. Ömer, Yezdicerd'in İslam'ı kabul etmeyen oğlunu katletmiş, Hz. Ali ise kızlara süre tanınmasını sağlamış ve onları Hz. Peygamber'in eşi Ümmü Seleme'nin himayesine vermiştir. Müslüman olan kızların evliliğine sıra geldiğinde Şehrbânû, aralarında Hz. Ömer, Hz. Osmân, Hz. Ali, Hz. Hasan, Yezîd b. Muâviye ve Hz. Hüseyin'in de bulunduğu eş adaylarından sonuncusunu seçmiştir. Şehrbânû'nun kendisini değil, Hz. Hüseyin'i seçmesi Yezîd'in Hz. Hüseyin'e karşı husûmetinin de başlangıcı olmuştur. ${ }^{74}$ Yezîd'in kıskançlık motifli düşmanlığının Kerbelâ olayına yol açması, olay sonrası Dımaşk'a götürülen esirler arasında bulunan Şehrbânû'yla evlenme konusunda ısrar etmesi ve Şehrbânû tarafından zekice planlanmış bir suikastle öldürülmesi gibi olay kurgusundaki bu destansı yapı maktelin sonuna kadar sürdürülmüştür. ${ }^{75}$

${ }^{73}$ Krș. Meclisî, Cilâu'l-'uyûn, 831-833; Abbaskulu Ağa Bakühanlı, Riyâzü'l-Kudüs (Azerbaycan Milli İlimler Akademisi Elyazmalar Enstitüsü, D-140), 79a.

${ }^{74}$ Saykalî, Ravzatü'ş-şühedâ, 1: 267-280; Altunmeral vd., “Bir Maktel-i Hüseyn Örneği”, 74-76.

75 Altunmeral vd., "Bir Maktel-i Hüseyn Örneği”, 76 vd. 
Üçüncü grup makteller Şehrbânû'yla ilgili diğer Türkçe maktellerde bulunmayan destansı unsurlarla birlikte, Hulefâ-yi Râşidîn dönemiyle ilgili Sünnî geleneğe uygun anlatım tarzıyla özellikle ikinci grup maktellerden ayrılmaktadır. Şehrbânû'nun eş tercihinin Yezîd'in Hz. Hüseyin'e karşı düşmanlığına neden olduğu, Kerbelâ olayının böyle bir intikam duygusu yüzünden geliştiğine dair olay kurgusuyla bu makteller, zamanla tarihî-edebî türe dönüşmüş makteller arasında tarihî anakronizmi en açı şekilde barındıran yapısıyla dikkat çekmektedir. Sadece Yezîd b. Muâviye'nin doğum tarihi (26/647 veya 27/648) dikkate alındığında, Hz. Ömer'in vefatından(ö. 23/644) üç-dört yıl sonra doğacak Yezîd'in, onun halifeliği döneminde Hz. Hüseyin'le birlikte Şehrbânû'nun eş adayları arasına katılmasının ve Hz. Hüseyin'e karşı intikam duygusu geliştirmesinin tarihî gerçeklikle örtüşmediği kesindir.

Üçüncü grup maktelleri farklı kılan bu destansı yapı, aynı zamanda bazı detaylarla müellifinin ve muhataplarının erken dönem İslam tarihi algısını da yansıtmaktadır. Nitekim Şehrbânû'nun Hz. Ömer döneminde Medine'ye getirildiğine ve halifeyle aralarında tatsızlık yaşandığına dair 5 . imâm Bâkır'a nisbet edilen rivayette, Fars kültürü ve Sâsânî hanedan ailesine yaklaşımı açısından Hz. Ömer ve Hz. Ali karşı kutuplar olarak gösterilirken; üçüncü grup Türkçe maktellerde ilgili rivayet üzerinde yapılan değişiklikler, Hz. Ali ve Hz. Ömer imajını önemli ölçüde değiştirecek kadar rivayeti Sünnî bir edisyondan geçirmiştir. Bu değişikliklere göre Hz. Ömer gibi Hz. Ali de "küffâr" Sâsânî hânedân ailesinin katlinden sorumludur. Nitekim kendi topraklarında Sâsânî hükümdarını katleden kumandan Hz. Ali, Medine’ye esir olarak getirilen veliahtı katleden de Hz. Ömer'dir. Hz. Ömer ve Hz. Ali'nin Şehrbânû'nun eş adayları arasından elenme nedeni ise kendilerinin Kisrâ ailesinin erkeklerinin katilleri olmalarıdır. ${ }^{76}$ Buna rağmen olayın sonunda Hz. Ömer bir halife olarak hutbe okumuş, Şehrbânû'yla Hz. Hüseyin'in nikahını kıyarak gençlere hayır duada bulunmuştur. ${ }^{77}$

$\mathrm{Bu}$ maktellerde zamanından erken doğarak(!) Hz. Ömer dönemine yetişen, Şehrbânû'nun eşi olma şansını Hz. Hüseyin'e kaptıran Yezîd b. Muâviye imajıyla, bir taraftan maktel okurları Kerbelâ'ya götüren sürecin siyâsî nedenlerinden uzaklaştırılırken, diğer taraftan Yezîd'in halifeliğinin mimarı olarak babası Muâviye b. Ebû Süfyân'ın olaylarla ilişkisi de en aza indirilmektedir. Bu sebeple bahsi geçen maktellerde bazen savunmacı bir yaklaşımla ideal bir Muâviye imajı çizilmekte veya Hz. Ali'den sonra

${ }^{76}$ Altunmeral vd., "Bir Maktel-i Hüseyn Örneği”, 72-73.

${ }^{77}$ Saykalî, Ravzatü'ş-şühedâ, 1: 278. 
yönetime Yezîd'in geldiği ve Hz. Hasan'ın zehirletilmesi gibi olumsuzlukları gerçekleștirdiği şeklinde anakronizme gidilerek Muâviye'den hiç sözedilmemektedir. ${ }^{78}$ Olay kurgusu açısından birinci grup maktellere yakın olan ve iyi karakterler için sık sık "Sünnî" ifadesinin kullanıldığı anonim Der Beyân-i Sergüzeșt-i İmâm Hüseyin'de benzer durum mevzû bahis olup, destansı bir kurgu üzerinden Muâviye b. Ebû Süfyân'la ilgili olumlu bir imaj çizilmiş ${ }^{79}$, ayrıca tarihî gerçekliğe uymayan bilgilerle Hz. Âişe'nin ${ }^{80}$ de maktelin şahıs kadrosuna dahil edilme gereği duyulmuştur. Bu durum bahsi geçen maktellerin destansı yapısının yanı sıra, Arapça ilk örneklerinden farklı, Farsça örneklerinden çok uzak olacak kadar, muhtemelen Türk toplumlarındaki bazı sûfî çevrelere özgü olarak, sahabîlerin de katıldığı Cemel, Sıffîn ve Kerbelâ vak'ası gibi İslam tarihinin erken dönem olaylarına yaklaşımının yansıması gibi değerlendirilebilir.

\section{Sonuç}

Genel anlamda Müslümanlar için $\mathrm{Hz}$. Peygamber'in torunu $\mathrm{Hz}$. Hüseyin'in soyunu devam ettiren oğlunun, özel olarak İmâmiyye'nin 4. imâmı Ali b. Hüseyin Zeynelâbidîn'in annesi olduğu ileri sürülen "Şehrbânû"yla ilgili Arapça, Farsça ve Türkçe belli başlı maktel örnekleri karşılaștırmalı olarak incelendiğinde aşağıdaki sonuçlara ulaşılmaktadır:

Mezhebinden bağımsız olarak Ebû Mihnef, Ebü'l-Ferec el-İsfahânî, Taberânî, İbn Tâvûs, İbn Nemâ Hillî gibi müelliflerin II.-VII./VIII.-XIII. yüzyıllara ait Arapça maktellerinde Kerbelâ'da bulunan Ehl-i Beyt kadınları, Zeyneb bt. Ali başta olmak üzere Ümmü-külsûm, Rukiyye, Sükeyne vs. gibi Ali-Fâtıma evladına mensup olup, Hz. Hüseyin'in eși veya Ali b. Hüseyin Zeynelâbidîn'in annesi olarak Șehrbânû'dan (veya erken dönem kaynaklarında geçen diğer isimlerinden) sözedilmemektedir. Müstakil bir maktel olmamakla birlikte, Hz. Hüseyin'in biyografisi bağlamında Kerbelâ olayına geniş yer verdiği Menâkibü Âl-i Ebî Tâlib isimli eserinde İranlı alim İbn Şehrâşûb'un Hz. Hüseyin'in eşi olarak Sâsânî hükümdarının kızı Şehrbânû'yla ilgili aktardığı bilgiler, Kerbelâ olayı bağlamında Arapça

78 Altunmeral vd., “Bir Maktel-i Hüseyn Örneği”, 76-77.

${ }^{79}$ Değirmenci, Der Beyân-i, 37-41.

$80 \mathrm{~Hz}$. Ali'nin hançerle yaralanması, Hz. Hasan'ın zehirlenmesi gibi olayların yașandığı zamanda Zeyneb, Ümmü-külsûm ve Rukiyye gibi ağlayan Ehl-i Beyt kadınları sırasında Şehrbânû'yla birlikte "Âyişe-yi Sıddîka" veya "Hazret-i Âyişe Ana"nın da ismine rastlamaktadır (Değirmenci, Der Beyân-i, 45, 48). Bu husus, Hz. Ali ve Hz. Hasan dönemleriyle ilgili kronolojik açıdan bir sorun taşımamakla birlikte, 58/678 yılında vefât etmiş Hz. Aişe'nin, 61/680 yılında vukû bulmuş Kerbelâ olayına da katılmış gibi gösterilmesi; Hz. Hüseyin'in savaș meydanına çıktığı sırada ağlayan veya uğradıkları zulüm dolayısıyla Dımaşk camisinde feryâd eden Ehl-i Beyt kadınları arasında da Ümmü-külsûm, Rukiye ve Şehrbânû'yla birlikte "Ayișe-yi Sıddîka"nın zikredilmesi tarihî gerçekliğe uymamaktadır (Değirmenci, Der Beyân-i, 68, 81). 
kaynaklarda konunun ele alındığı ilk örneklerden biri olarak değerlendirilebilir. Şahıs kadrosunda Şehrbânû'ya özel yer veren son yüzyıllara ait bazı Arapça maktellerin ise Fâzıl Derbendî ve Abbâs Kummî gibi Türk-Fars kültür çevrelerinde yetişen, İmâmiyye mensubu gayr-i Arap din alimleri tarafından telif edildiği görülmektedir.

Hz. Hüseyin'in, isminin zikredilmesi önemli görülmeyen gayr-i Arap eşiyle ilgili Arapça maktellerdeki bu yaklaşımdan farklı olarak, Ravzatü'şşühedâ ve Cilâ'u'l-'uyûn gibi Farsça maktellerin şahıs kadrosunda etkin bir konuma yerleştirilmiş Sasanî prensesi olarak Şehrbânû imajıyla karşılaşılmaktadır. Allahın iki seçkin kavminin -Araplardan Hâşim oğulları ile Acemlerden Farsların- soyundan olması bağlamında Ali b. Hüseyin Zeynelâbidîn için geliştirilen "peygamberlikle melikliği birleştiren" veya “İbnü'l-hiyarateyn” anlayışı üzerinden her iki makteldeki Şehrbânû imajının, genel olarak Sasani imparatorluğuna kültürel varislik ve Fars millî kimliğinin yüceltilmesi, özel olarak "imamların anası" olması hasebiyle Hz. Fâtıma ile eşdeğer konuma yerleștirilmesi üzerine kurulduğu söylenebilir.

Bu önemli ortak yönüne rağmen Şehrbânû'nun hayatıyla ilgili Farsça makteller arasında temel farklılıklar da bulunmaktadır. Şehrbânû'nun Hz. Hüseyin'le evlenmesinin arkaplanından bahsetmeyen Kâşifî'den farklı olarak, Meclisî evlilik olayı üzerinden Farsça anlamayan, Sâsânî prensesine karşı kötü davranan Hz. Ömer ile Farsça konuşan, Sasanî hânedanının son üyelerini koruma altına alan, soylu acem gelininin oğluna kendisinden sonraki en hayırlı insanı doğuracağını müjdeleyen Hz. Ali imajını oluşturmaktadır. Meclisî, Şehrbânû imajını onun Hz. Hüseyin'le evlendiği döneme kadarki, Kâş̧ifî ise o dönemden sonraki hayatı üzerinde kurgulamaktadır. Kâşifínnin Şehrbânû'su Kerbelâ sırasında ve Dımaşk yolculuğunda acı çeken Ehl-i Beyt'le özdeşleşen, maktelin okunduğu halk kitleleriyle arasında empati kurulan acınası bir Sâsânî prensesiyken, Meclisînnin Şehrbânû'su güzelliğiyle Medineli Arap kızlarını hayran bırakan, Hz. Peygamber, Hz. Fatıma ve Hz. Ali'nin ruhânî/manevî kılavuzluğuyla Hz. Hüseyin'le kutsal izdivâca giren, Ali b. Hüseyin'i doğurma misyonuyla birlikte hayatı da sona eren, bu süreç içerisinde her türlü Arap saldırısına karşı dokunulmazlığı garanti edilen asîl bir Sâsânî prensesidir.

Büyük bir kısmı şahıs kadrosunda Şehrbânû'ya özel yer veren Türkçe makteller olay kurgusu açısından üç kısımda tasnif edilebilir: 1) Yûsuf-ı Meddâh'ın Maktel-i Hüseyn'i etkisinde yazılanlar; 2) Kâşifînin Ravzatü'şşühedấ'sının çevirileri; 3) Saykalînnin Ravzatü'ş-şühedâ'sına yakın olanlar. Maktellere İslâm tarihinin en elîm olaylarından olan Kerbelâ'nın bir trajedi 
olarak dinleyicilere sunumu olarak bakılırsa, birinci grup Türkçe maktellerdeki Şehrbânû bazı çocuklarını savaş meydanında, yeni doğan bebeğini meşakkatli Dımaşk yolculuğunda kaybeden, geri kalan çocuklarını koruyup kollamaya çalışan ve yolculuk sırasında hastalanarak vefât eden bir anne olup, bu anlamda trajedinin anne simgesidir.

Ravzatü'ş-şühedâ etkisindeki ikinci grup Türkçe maktellerde $\mathrm{Hz}$. Hüseyin'in eşi ve çocuğunun annesi olması bağlamında Şehrbânû'yla ilgili veriler büyük oranda Kâşifî'nin makteline uygun olmakla birlikte, Fars kimliğine özel vurgu yapılmaması açısından Farsça orijinalinden ayrılmaktadır. Ravzatü'ş-şühedâ'nın Türkçe çevirilerinde Yezdicerd b. Şîrûye'nin kızı Şehrbânû'nun Sâsânî hanedanının devamcısı olarak Hz. Peygamber'in her iki torununun soyunu devam ettiren özelliğinden bahsedilmemekte, "peygamberlikle melikliğin birleşmesine" vesile olduğu gündeme getirilmemektedir.

Sabir Saykalî'nin Ravzatü'ş-şühedâ'sı ve anonim bir maktelle örneklendirilen üçüncü grup Türkçe makteller, Şehrbânû'yla ilgili önemli ölçüde destansı bir olay kurgusuna sahiptir. Şehrbânû'nun Hz. Hüseyin'le evliliği bağlamında 5. imâm Bâkır'a nisbet edilen ve Hz. Ömer-Hz. Ali karşıtllğı üzerine kurulmuş rivayet, bu maktellerde Sünnî bir edisyondan geçirilerek değiştirilmiştir. Bu değişiklik bir taraftan Hz. Ömer döneminde Şehrbânû'yla evlenme şansını kaybeden Yezîd b. Muâviye'nin Hz. Hüseyin'e karşı geliştirdiği düşmanlığın Kerbelâ olayına neden olduğunu ön plana çıkarırken, diğer taraftan eski versiyonunda Sâsânî hânedan üyesine karşı tavrı bağlamında karşı karşıya getirilen Hz. Ömer ve Hz. Ali imajlarını da önemli şekilde dönüştürmektedir. Buna göre dönemin halifesi Hz. Ömer gibi, ordu komutanı olarak Hz. Ali de Sâsânî hânedan üyelerinin katlinden sorumludur. Dahası, Şehrbânû'nun eş adayları arasından elenmekle birlikte bir halife vasfiyla Hz. Ömer hutbe okuyarak onunla Hz. Hüseyin'in nikahını kıymış ve hayır duada bulunmuştur. Hz. Hüseyin-Yezîd arasındaki ilişkilerin siyâsî boyuttan kişisel adavete indirildiği, oğlunun veliahtlığı dolayısıyla Muâviye b. Ebû Süfyân'ın gündeme getirilmediği, Hz. Ali'nin Sâsânî hanedan üyelerinin katlinde ortak olduğu, Hz. Ömer'in Şehrbânû ve Hz. Hüseyin'in nikahını kıydığı, Kerbelâ sonrasında Yezîd'in Şehrbânû tarafından katledildiği gibi gerçek dışı unsurlar bahsi geçen maktellerin destansı yapısını göstermenin yanı sıra, Arapça ve Farsça örneklerinden farklı olarak, Türk toplumlarında bazı tasavvufî çevrelerin erken dönem İslam tarihi olaylarına bakışıyla yoğrulmuş maktel yazımı olarak da değerlendirilebilir. 
bir tarihî figür gibi gözükmeyen Şehrbânû'nun, Farsça maktellerde önemli bir millî-dinî kimlik unsuru olarak ön plana çıkarıldığı, bir anlamda maktelin Farslaştırılmasına hizmet ettiği söylenebilir. Şehrbânû'yla ilgili olay kurgusu açısından üç kategoride tasnif edilebilen Türkçe maktellerin birinci grubunda Şehrbânû elîm bir olay olan Kerbelâ'da yaşadığı evlat acılarıyla trajedinin anne simgesiyken, Kâşifî etkisindeki ikinci grup maktellerde seçilmiş Fars kimliği vurgulanmaksızın Sasani prensesi olarak Hz. Hüseyin'in eşi ve çocuğunun annesidir. İlk örnekleri Arapça tarihî metin olarak telif edilen maktellerin tarihî-edebî türe dönüşmesi sürecinde anakronik yapısıyla dikkat çeken üçüncü grup Türkçe maktellerde ise kendisine millîdinî kimlik açısından herhangi bir rol biçilmeksizin Şehrbânû, Kerbelâ olayının siyâsî nedenlerini arka plana iterekYezîd b. Muâviye'nin Hz. Hüseyin'e karşı kişisel adavetini öne çıarmaya hizmet eden destanlaştırılmış olay kurgusunda önemli bir karakter olarak yer almaktadır.X.

\section{KAYNAKÇA}

ABBAS KUMMÎ,ibn Muhammed Rıza. Nefesü'l-mehmûn fî musîbeti Seyyidine'lHüseyni'l-Mazlûm, Beyrut: Dârü'l-Mehecceti'l-beydâ, 1992.

ALTUNMERAL, Mehmet vd. "Bir Maktel-i Hüseyn Örneği”. Sûfi Araştırmaları - Sufi Studies 1/1 (2010): 61-105.

AMIR-MOEZZI, Mohammad Ali. "Shahrbānū, Dame du Pays D’Iran et Mère Des Imams: Entre L'Iran Préislamique Et Le Shiisme Imamite", Jerusalem Studies in Arabic and Islam 27 (2002): 497-541.

AZİOVA, Elnure. Kerbelâ Vak'ası. İstanbul: Marmara Üniversitesi, SBE, Yüksek Lisans Tezi, 2001.

BAKÜHANLI, Abbaskulu Ağa. Riyâzü'l-Kudüs. Azerbaycan Milli İlimler Akademisi Elyazmalar Enstitüsü, D-140. 1a-95a.

BEYHAKÎ, Ebü'l-Hasan Zâhirüddîn Ali b. Zeyd. Lübâbü'l-ensâb ve'l-elkâb ve'l$a^{\prime} k a ̂ b$. thk. Seyyid Mehdi Recâî. 2 Cilt. Kum: Âyetullâhi'l-'Uzmâ elMar'aşî, 1990.

BORRUT, Antoine, "Remembering Karbalā: the construction of an early Islamic site of memory", Jerusalem Studies in Arabic and Islam, 42 (2015): 249-282.

BOYCE, Mary. "Bībī Shahrbānū and the Lady of Pārs". Bulletin of the School of Oriental and African Studies. London: the University of London, 30/1 
(1967): 30-44.

CÂMİ-İ RÛMÎ (MISRÎ), Sa 'âdetnâme. Millet, Ali Emiri Trh., 000326, 1a-411a.

DEĞİRMENCI, Zühre. Der Beyân-i Sergüzeşt-i İmâm Hüseyin. Çanakkale: Onsekiz Mart Üniversitesi, SBE, Yüksek Lisans Tezi, 2009.

DÎNEVERÎ, Ebû Hanîfe Ahmed b. Dâvûd. Ahbâru't-tıvâl. thk. 'Abdülmünîm Âmir. yy. ty.

EBÛ MİHNEF, Lût b. Yahyâ. Maktelü'l-Hüseyn ve masra'u ehli beytihi ve ashâbihi fi Kerbelâ. Kum: Menşûrât-i Rızâ, 1391.

EREN, Hulusi. Dârendeli Kâtipzâde Bekâyî-Maktel-i Hüseyn: Inceleme-Tenkitli Metin-Sözlük Dizin. Ankara: Hacettepe Üniversitesi, SBE, Yüksek Lisans Tezi, 2014.

ERTEKİN, Ertuğrul. "Arapça, Farsça ve Türkçe Maktel-i Hüseyinler", Âşinâ Dergisi 7/23-24 (2006): 79-107.

FÂZIL DERBENDÎ, Ağa İbn Abid ibn Ramazan. İksîru'l-'ibâdât fî esrâri'şşehâde. thk. Şeyh Muhammed Cumabâdî. 3 Cilt. Manama: Şirketü'lMustafâ li'l-hademâti's-sakâfiyye, 1994.

GÜLSÜM, Mehmet Akif. Yahyâ Bin Bahşînnin Maktel-i Hüseyin adlı mesnevisi (İnceleme ve metin), Kırklareli: Kırklareli Üniversitesi, SBE, Yüksek Lisans Tezi, 2019.

HACI NÛREDDÎN EFENDİ. Maktel-i Hüseyin. haz. Mehmet Karaarslan. İstanbul: Önsöz Yayıncllık, 2012.

İbn KUTEYBE, Ebû Muhammed Abdlulah b. Müslim. Fazlu'l-'Arab ve't-tenbîh 'alâ 'ulûmihâ. thk. Velîd Mahmûd Hâlis. Ebûzabî: el-Mecmaü's-Sekâfî, 1998.

İbn KUTEYBE, Ebû Muhammed Abdullah b. Müslim. el-Ma'ârif. thk. Servet 'Ukkâşe. Kahire: Dârü'l-Ma'ârif, 1981.

İbn NEMÂ,Câfer b. Muhammed el-Hillî. Müsîrü'l-ehzân va münîrü sübüli'leşcân. Kum: Matba'atü'l-Emîr, 1406.

İbn SA'D, Ebû Abdullah Muhammed. Kitâbü't-Tabakâti'l-Kebîr. thk. Ali Muhammed Ömer. 10 Cilt. Kâhire: Mektebetü'l-Hancî, 1421/2001.

İbn ŞEHRÂŞÛB, Ebû Câfer Reşîdüddin Muhammed b. Ali. Menâkıbu âli Ebî Talib. thk. Yûsuf el-Bekâ'î. 4 Cilt. Beyrut: Dârü'l-Edvâ, 1412/1991.

İbn TÂVÛS, Ebü'l-Kâsım Radıyyüddîn Ali b. Mûsâ. el-Lühûf fî katle't-tüfûf. Beyrut: Müessesetü'l-'ilmiyyi li'l-matbû'ât, 1414/1993.

İSFAHÂNÎ, Ali b. Hüseyin b. Muhammed Ebü'l-Ferec. Mekâtilü't-Tâlibiyyîn. thk. es-Seyyid Abbas Ahmed Sakr. Beyrut: Dârü'l-Ma'rife, 1946. 
KÂŞīFî, Mevlânâ Kemâlüddîn Hüseyin b. Alî-i Beyhakî. Ravzatü'ş-şühedâ. thk. Hasan Zülfikârî - Ali Tasnimi. Tahran: Mu'în, 1390.

KÜLEYNî, Ebû Câfer Sıkatü'l-İ̀lâm. el-Usûl mine'l-Kâfî. thk. Ali Ekber elGaffârî. Tahran: Dârü'l-Kütübi'l-İslâmiyye, 1363.

LÂMî̂ ÇELEBÎ, Maktel-i Âl-i Resûl. thk. Ertuğrul Ertekin. İstanbul: Kevser Yayınları, 2012.

MECLISÎ̃, Muhammed Bâkır b. Muhammed Takî. Cilâu'l-'uyûn. thk. Seyyid Alî İmâmyân), Kum: yy. ty.

MÜBERRED, Ebü'l-Abbâs Muhammed b. Yezîd b. Abdilekber. Kitâbüll-Fâzıl ve'l-mefzûl. thk. Abdülazîz el-Meymenî. Kâhire: Dârül-kütübi'lMisriyye, 1995.

NAĞISOYLU, Möhsün, Seçilmiş Әsarlari, 2 Cilt. Bakı: Elm, 2017.

ÖZÇELIKK, Kenan. "Lâmiî Çelebi'nin Kitâb-ı Maktel-i Âl-i Resûl'ü". Bursalı Lâmiî Çelebi ve Dönemi Sempozyumu 2011: Bursa (ed. Bilal Kemikli Süleyman Eroğlu) Bursa: Bursa Büyükşehir Belediyesi, 2011, 273-279.

ÖZÇELIK, Kenan. Aşık Çelebi: Ravzatü'ş-şühedâ tercümesi: İnceleme - metin. İstanbul: Doğu Kütüphanesi, 2016.

ÖZÇELIK, Kenan. Yûsuf-ı Meddâh ve Maktel-i Hüseyn: İnceleme - Metin Sözlük. Ankara: Ankara Üniversitesi, SBE, Yüksek Lisans Tezi, 2008.

ÖZIL, Sibel. "Maktel-i Hüseyinler Hakkında Bir Bibliyografya Denemesi”. Türk Kültürü ve Hacı Bektaş Veli Araştırma Dergisi 83 (2017): 31-48.

SAFFÂR KUMMÎ, Ebû Ca'fer Muhammed b. Hasan b. Ferrûh. Besâirü'd-derecât fî fazâili Âl-i Muhammed. thk. Müessesetü'l-İmâmi'l-Mehdî. 2 Cilt. Kum: I'timâd, t.y.

SAVANT, Sarah Bowen. The New Muslims of Post-Conquest Iran: Tradition, Memory, and Conversion, New York: Cambridge University, 2013.

SAYKALÎ. Ravzatü'ş-şühedâ: İnceleme - metin - dizin (I. bölüm 1-236). thk. Talip Yıldırım. 1 Cilt. İstanbul: Bilgeoğuz Yayınları, 2016.

STOREY, Charles Ambrose. Persian Literature: a bio-bibliographical survey. 2 Cilt. London: The Royal Asiatic Society, 1970-72.

ŞEYH MÜFÎD, Ebû Abdullah İbnü'l-Mu'allim Muhammed. el-İrşâd fî ma'rifeti hücecillâhi 'ale'l-ibad, 2 Cilt. Beyrut: Müessese Âli Beyt ve ihyâu't-turâs, $1429 / 2008$.

ŞEYH SADÛK, Ebû Câfer Muhammed b. Ali b. Hüseyin. 'Uyûnü ahbâri'r-Rızâ, 3 Cilt. yy.ty.

TABERÂNî. Ebü'l-Kâsım Süleyman b. Muhammed. Maktelü'l-Hüseyn. thk. 
Muhammed Şecâ Dayfullâh. Küveyt: Dârü'l-evrâdi, 1412/1992.

TABERÎ, Muhammed b. Cerîr. Târîhü't-Taberî: Târîhu'l-ümem ve'l-mülûk. thk. Muhammed Ebü'l-Fadl İbrâhîm. 11 Cilt. Beyrut: Dârü Süveydân, 1967. TÜRKOĞLU, Serkan. “Türk Edebiyatında Maktel-i Hüseyinler ve Bekâînin Kitâb-ı Kerbelâ Mesnevisi", Türkiyat Araştırmaları Enstitüsü Dergisi, 58, Erzurum 2017, 107-128.

YA'KUBÎ, İbn Vazıh Ahmed b. İshâk b. Cafer., Târîhu'l-Ya'kubî, 3 Cilt. Necef: Mektebetü'l-Haydariyye, 1384/1964.

YÜKSEL, Yahya. Nevruz Bin İsa'nın Manzume-i Kıssa-i Kerbelası: Varak 70a139b. Ordu: Ordu Üniversitesi, Sosyal Bilimler Enstitüsü, Yüksek Lisans Tezi, 2012.

站站站 


\title{
FROM THE PALACE OF KISRĀ TO THE DESERT OF KARBALĀ: SHAHRBĀNŪ IN MAQTALS BETWEEN A NATIONAL-RELIGIOUS IDENTITY ELEMENT AND A HISTORICAL-LEGENDARY FIGURE
}

\author{
Elnura AZIZZOVAa
}

\section{Extended Abstract}

Comparative analysis of certain Arabic, Persian and Turkish maqtals shows that the given data about Shahrbānū, who is claimed to be the mother of 'Alī ibn Husayn Zaynalābidīn, the 4the imām of Imāmiyya in particular and the son continuing the Prophet Muhammad's grandson Husayn ibn 'Alī's bloodline in general, is crucially different. Regardless of their religious sects, Arabic maqtal writers of the 2nd-7th/8th-13th-centuries such as Abu Mihnnaf, Isfahānī, Ṭabarānī, Ibn Tāwūs, and Ibn Namā al-Hillî emphasize the role of descendants of Fāṭima and 'Alī's family, especially Zaynab bint 'Alī, Ummu Kulthūm, Ruqayya, Sukayna etc. as the woman members of Ahl al-Bayt participating at the Karbalā Event. However, these authors do not mention the so-called Shahrbānū or any other name mentioned in the early sources for 'Alī ibn Husayn Zaynalābidīn's mother. Despite not being an independent maqtal, Manāqib Āli Abū Tãlib by the Iranian scholar Ibn Shahrasūb is one of the first Arabic sources where the author dedicates a significant chapter for the biography of Husayn ibn 'Alī and gives information about the participation of princess Shahrbānū, the daughter of the Sāsānian king Yazdajird III, at the Karbalā Event as the wife of the 3rd imām. As well as the late Arabic maqtals giving a special place to Shahrbānū among the participants of the Karbalā Event are written by Fāzıl Darbandī and 'Abbās Qummī, the non-Arab Imāmiyya scholars from the Turkish or Persian

\footnotetext{
a Assoc. Prof., Azerbaycan Institute of Theology, elnuraazizova@ait.edu.az
} 
cultural environment.

Unlike early Arabic maqtal writers' silence about 'Alī ibn Ḥusayn's non-Arab mother, whose name is not considered important to be mentioned, the Sāsānian princess Shahrbānū appears as an important figure in the Persian maqtals such as Rawḍat al-shuhadā and Jalâ’ al- 'Uyûn. It is worth mentioning that, both Persian maqtals contain conflicting data regarding the main events of Shahrbānū's life stages. For instance, in his maqtal titled Jalâ' al- 'Uyûn, Muhammad Majlisī develops the image of Shahrbānū on the events occurring until her marriage to Ḥusayn ibn 'Alī, while Kāshifī, the author of Rawdat alshuhadā, fictionalizes this image on her postmarital period. Unlike Kāshifi, who does not mention the background of Shahrbānū's marriage to Husain ibn Ali, Majlisĩ emphasizes the marriage event based on the narrative attributed to the 5th imām Bāqir, which brings caliph 'Umar ibn al-Hatțāb over against 'Alī ibn Abū Tâalib, where the former does not understand the Persian and misbehaves towards the Sasanian princess, while the latter speaks Persian fluently, protects the member of the Sāsānid dynasty, and heralds his son Husayn ibn 'Ali foretelling that the noble foreign bride Shahrbānū - will give birth to the next best virtuous man after him. To sum up, Shahrbānū described by Kāshifĩ is a wretched Sāsānian princess who is identified with the Ahl al-Bayt suffering from te Karbalā Event to Damascus, thus empathized with the audience of Rawdat al-shuhada. Whereas, Shahrbānū presented by Majlisī is a noble Sāsānian princess who glamorizes Medinnian maidens with her beauty, entered into holy matrimony with Husayn ibn 'Alì through the spiritual guidance of the holy family - the Prophet Muhammad, his daughter Fāțima and son in law 'Alī ibn Abū Taalib , and finally, whose life ended up with the mission of giving birth to 'Ali ibn Husayn Zaynalābidinn, and during all this process her privateness was protected against all kinds of Arab attacks. Despite all these fundamental differences, the image of Shahrbānū in both maqtals is based on imām Zaynalābidīn's special status as the descendant of God's two chosen folks the Banū Hāshim from the Arabs and the Persians from the 'Adjam - thus combining the "prophethood and kingship" or being "the son of the two nobles" (ibn al-hiyaratayn). In conclusion, the image of Shahrbānū in these Persian maqtals is generally based on the cultural heirship of the Sāsānids and the glorification of the Persian national identity. In particular, she is placed in a position equal to the Prophet Muhammad's daughter Fāṭima, because of being "the mother of imāms".

|238| The Turkish maqtals, many of which give a special place to Shahrbānū in their storyline, can be classified into three parts in terms of fiction. The first 
group is the maqtals written under the influence of Maqtal al-Husayn by Yūsuf Maddāh, accepted as the first written maqtal in Turkish. The second group constitutes the direct or indirect translations of Rawdat al-shuhadā by Kāshifi. The last group is ones similar to the Rawḍat al-shuhadā by Șābir Sayqalī. Considering the maqtals like the presentation of the Karbalā Event to the audience as a tragedy - undoubtedly one of the most painful events in the history of Islām - in the first group Turkish maqtals Shahrbānū is presented as "the mother symbol of tragedy" who tragically lost some of her children on the Karbalā battlefield and suffered a miscarriage on a gruelling journey to Damascus; who tried to protect and take care of her remained children, finally, got ill and died in Damascus. In the second group Turkish maqtals, the data about Shahrbānū as Ḥusayn ibn 'Alī's wife and mother of his son is mostly in line with Kāshifî's maqtal but is different from its Persian original in terms of not putting special emphasis on Persian national identity. In the Turkish translations of Rawdat al-shuhadā, neither it is mentioned that through Shahrbānū, the daughter of Yazdajird III, continued bloodline of the Prophet's both grandchildren, especially Husayn ibn 'Alī, nor it is referred that she caused the "unification of the prophethood and kingship". The third group of Turkish maqtals, exemplified in the article by Rawdat al-shuhadā by Șābir Sayqalī and an anonymous maqtal, have a significantly epic storyline about Shahrbānū. The narration, which in its original version is attributed to the 5th imām Bāqir on Shahrbānū's marriage to Ḥusayn ibn 'Alī and emphasizing the polarization between the Caliph 'Umar ibn al-Huațâb and 'Alī ibn Abū Tâalib, has been changed by passing through a Sunnī edition in the third group maqtals. On the one hand, this change highlights that the hostility which Yazīd ibn Mu'āwiya develops against Ḥusayn ibn 'Alī and causes the Karbalā Event, originated since then the former had lost his chance to marry Shahrbānū during the Caliph Omar's reign, on the other hand, it also significantly changes the images of the Caliph Omar and 'Alī ibn Abū Țālib, who in the original version of the narrative had been presented as the counterparts in the context of their attitude towards the royal of the Sāsānian dynasty. According to this change, just like the Caliph Omar, 'Alī ibn Abū Țālib as the army commander is responsible for the assassination of the royals of Sāsānian dynasty. Moreover, although 'Umar ibn al-Hुatțāb had been eliminated among the co-candidates of Shahrbānū, as a caliph he recited a sermon, performed the marriage of Shahrbānū with Husayn ibn 'Alī, and blessed them. The reduction of the relations from political dimension to personal animosity between Ḥusayn ibn 'Alī and Yazīd ibn Mu'āwiya; keeping Mu'āwiya ibn Abū Sufyānout of the processes and not mentioning 
his appointment of Yazīd as his heir apparent; presenting 'Alī ibn Abū Taalib's as a partner in the assassination of the members of the Sassanid dynasty; the murder of Yazīd by Shahrbānū after the Karbalā Event in Damascus, all these unreal narrative elements show the epic structure of the aforementioned maqtals. However, these details can also be considered a reflection of certain Turkish Sufi orders on the particular events of the early period of Islamic history, which changes this group of maqtals dramatically in comparison to referred Arabic and Persian examples of the genre.

Keywords: History of Islam, Karbalā Event, Ḥusayn Ibn 'Alī, Maqtal, Shahrbānū.

然濯 